\title{
DJ Goa GIL \\ Kalifornian Exile, Dark Yogi and Dreaded Anomaly
}

\author{
$\bullet$ Feature Article $\longrightarrow$ \\ Graham St JOHN \\ UNIVERSITY OF QUEENSLAND
}

\begin{abstract}
Connecting three generations of music enthusiasts, Goa Gil is an imposing figure in the world of psychedelic trance. If the title of his 2007 compilation registers intent, he is a Worldbridger. Bristling with motifs of world sacred sites and appropriated "tribal" icons, with Gil seated cross-legged upon the apex of a Mayan temple, the album's cover artwork confabulates the physical, spiritual and cultural worlds he professes to bridge. Leading world-wide "trance dance rituals" Goa Gil operates under the guise of a "techno-shaman", a "cyber-baba" and a selector/mixer of traditions whose rituals are reputedly timeless and universal. But this intent is performed amid a highly mobile lifestyle spread across diverse psychedelic music cultures, scenes and sensibilities in discrete times and places. From the 1960s Haight-Ashbury psychedelic rock scene, to the psychedelic jam band scene on Anjuna beach, Goa, India, in the 1970s, to the adoption of electronic music in a DJ-led scene in the 1980s, to the birth of "Goa trance" in the 1990s, to his selection, production and performance of dark psychedelic trance from the 1990s onwards, DJ Goa Gil's life spans a breathtaking panorama of this-worldly psychedelic scenes. Gil is a freak bricoleur, an anomalous figure who evades modest circumscription. A Californian exile and sanctioned Shaivite practitioner with a professional hankering for darkpsy (as a DJ-producer), a hippie broker of the "Cosmic Spirit" and a post-apocalyptic punk, he is a spiritual authority and cultural outlaw touring the planet with an improbable mix of semiotic and sonic baggage. What's more, celebrated as a champion of the "Goa vibe" or derogated as an accomplice to its demise, Gil is a controversial figure who is the embodiment of considerable ambivalence. This article explores this holiest of anomalies in the world of DJing.
\end{abstract}

KEYWORDS: Goa trance, Goa Gil, psytrance, techno-shaman, nomos/anomalous, ecstatic dance, cultural exile

Dancecult: Journal of Electronic Dance Music Culture 3(1): 97-128 ISSN 1947-5403 @2011 Dancecult http://dj.dancecult.net DOI 10.12801/1947-5403.2011.03.01.05

dsincecult 
Angel's Camp, near Santa Cruz, California, 11-12 October 2006. It's well past midnight, as psychedelic savants and nouveau freaks amass under redwoods. Overhead, the cosmos is vast and the stars are blinking back on those gathered in the clearing, soon to be buried under an avalanche of "killah" bass-patterns. Goa Gil is wreaking his usual havoc on those who've arrived to celebrate his $55^{\text {th }}$ birthday. The "Godfather of trance" performs within a makeshift shrine, pushing darkpsy from a pair of Sony TCD-D8 DAT Walkmans, ${ }^{1}$ under Tibetan flags, over a statue of Ganesh with a Buddha decorated in plastic lotus flowers seated nearby. Behind dark shades and with grey dreadlocks knotted back, Gil is back-dropped by a fluorescent Shiva-Shakti mandala tapestry and another featuring Lord Shiva in the form of Nataraja, the cosmic dancer, all illuminated under black light. Next to his DAT players, Gil burns incense, has placed framed photographs of his gurujis, and controls a device with a red pulsing, the Devanagari sign for $O m$, the sacred syllable in the Indian religions. As a hallmark of Gil's parties, the rate of the flashing is synched with the beats, which may range in excess of 180 BPM through the night and into the day. Behind the shrine-stage is Gil's Porta-Potty. At the helm, and without relent, he will punish this freak congregation for 24 hours.

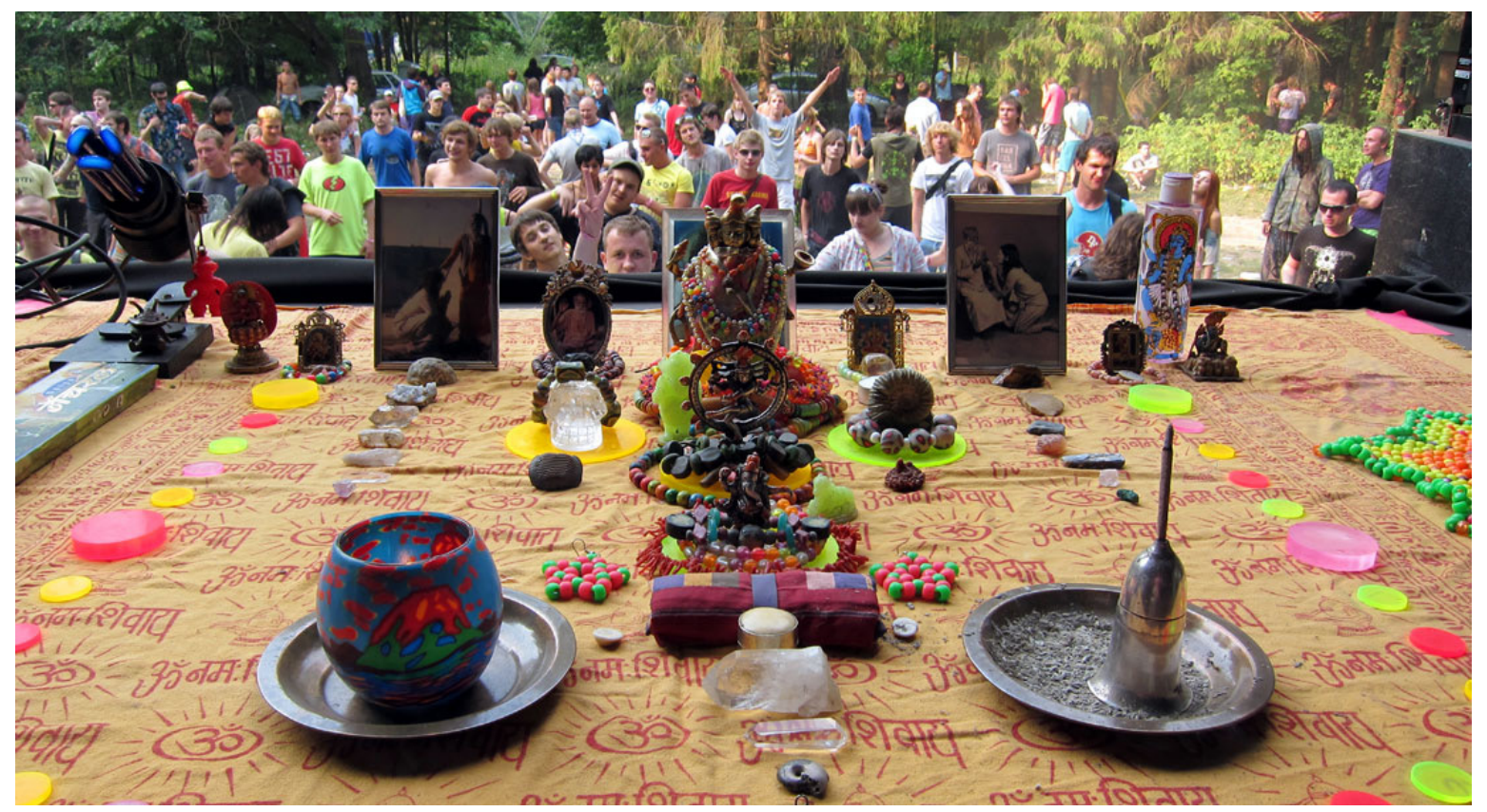

Figure 1. Goa Gil's DJ altar, Moscow 2010. Photo: Goa Gil.

GRAHAm ST John is an Honorary Research Fellow at the Centre for Critical and Cultural Studies at the University of Queensland. His latest books include Technomad: Global Raving Countercultures (Equinox, 2009) and the edited collection The Local Scenes and Global Culture of Psytrance (Routledge, 2010). His forthcoming book with Equinox is Global Tribe: Spirituality, Technology and Psytrance. He is the Executive Editor of Dancecult. See: < http://www.edgecentral.net $>$. Email: <g.stjohn@warpmail.net $>$. 
GOA GIL has had an integral role in the evolution of psychedelic trance (psytrance) from its roots in Goa, India, to its adoption in scenes around the world. Having arrived in Goa in 1970 fresh from San Francisco's acid rock scene, Gil would, 40 years hence, become a renowned selector and producer of dark psychedelic trance music, promulgating this genre in his trance dance "rituals" performed at locations around the world at least a decade before "darkpsy" became a recognized genre. He has also formed, with his wife, African dance instructor, percussionist and producer Ariane MacAvoy (and for some time Peter Ziegelmeier, aka Kode IV), the outfit The Nommos. In 2010, Gil performed some 22 gigs, many over 24 hours, at venues in India, Greece, Portugal, Russia, Japan, Israel, Mexico, Chile and other locations. Having led approximately 500 trance dance rituals, ${ }^{2}$ Gil is a spiritual authority for freaks in the world psychedelic diaspora, with Michael McAteer, who produced a devotional BA thesis on Gil, casting him as a "mystagogue" (2002). The prestige he holds within the Goa/psytrance community is apparent in the collection Goa: 20 Years of Psychedelic Trance (Rom and Querner 2010) where Gil writes the first of 36 chapters. But while many owe gratitude to Gil's interventions, he attracts considerable controversy. In Victoria Bizzell's analysis, Gil is couched as the leading advocate of a "transnational neotribalism", whose "world without borders" is "an extension of a Western neo-colonialist mentality that sees the often-fabricated spiritual and ontological mythologies of 'other' cultures as ripe products for semiotic appropriation" (2008: 290). Recognizing that Goa trance and its progeny neither possess nor are possessed by a single figurehead, aesthetic or tribalism, this article addresses the ambivalence embodied by DJ Goa Gil; a man who is revered and reproved with equivalent passion. But then, Gil's practice is notoriously aberrant for this profession. For Goa Gil is not simply a DJ (and some will argue that he is not a "DJ" at all), but a religious specialist, an initiate in the Shaivite sect Juna Akhara, a cultural exile, a spiritual activist and a phenomenal anomaly.

Being ambiguous with regard to the law is the province of the electronic musician and performer, who hustles and mixes found sound as an art form, and who provides the sound track for dancescapes inhabited by those who enter experimental (and often unlawful) states of consciousness. In Chiara Baldini's (2010) view, this ambiguity is embodied by the Goa DJ, who, with charismatic dreadlocks, exotic tattoos and strange piercings, may be a target of desire and enmity, drawing diverse responses not unlike that met by Dionysus, the personification of cultic ambivalence. Destructive/creative, trickster-like, queer, a freak, a transgressor of rules, codes and boundaries, the DJ cuts an ambiguous figure and draws disparate yet extreme emotive responses across the community of transgressors/transgressed; with the ambivalence amplified if the DJ is a figure who, not unlike the shaman or the mystic, is reputedly mobile across transpersonal frontiers. In addition to being an embodiment of transgression, the DJ is integral to independent musical cultural movements. There has been very little scholarly attention given to the $\mathrm{DJ}$ as cultural activist, although it is implicitly recognized that DJs are, from Jamaican dancehall to hip hop, Detroit techno, psychedelic trance and dubstep, promoters and champions of a variety of causes and concerns, both unique to their communities of origin and integral to horizon campaigns (see Beck and 
Lynch 2009). Elsewhere (St John 2012, forthcoming), I explore the psytrance DJ as an outlaw figure, and have also factored the role of DJ performances into the arts of protest $(\mathrm{St}$ John 2009a). Psytrance is a potent liminal arena for the recombination of the outlaw and the activist, in no small part due to the exile sensibility inhering in the Goa tradition.

Psytrance has emerged from a tradition inhabited by the cultural exile who made his/ her departure from untenable conditions occasioned by the impossibilities of the "nuclear" family and the possibilities of "nuclear" war, that effected a notable impact on 1960s and 1970s forebears. Though it was not exclusively the case among proto-freak émigrés settling in Goa (consider Eight Finger Eddie's background as the child of Armenian immigrants in Depression-era Boston-see below), for the most part it was their privileged backgrounds that permitted Goa freaks to choose their exodus, that enabled their responses to outlawed practice, existential despair, disenchantment and cognitive dissonance already experienced as a product of middle-class lifestyles. However, the exodus was not simply the fulfillment of "advanced needs", but a reaction to inherited social, cultural and historical conditions. This is the career of the freak, the liberated man and woman, who, as opposed to the "political" exile-who is forced to vacate home/nation and may even become associated with a "government in exile" which desires a return to power-is a self-elected exile, driven by circumstance to dwell in a permanent state of departure from the maladies of modern life. Of course, the self-exile is also a political exile, in the sense that tobias c. van Veen (2010) has outlined for rave. As a "desertion from acceptable modes of collective and individual responsibility" and a participatory "absence of signs", rave's "passage through exodus enacts a defection or disappearance from politics (and its logic of representation) to the political" (van Veen 2010: 42; 41), which, in the dissolution of the distinction between labour and leisure, is recognized as a space of potential. The self-exile is a connoisseur of experience; of freedoms which rupture the conditions of self-hood associated with possessive materialism, nationalism and monotheism (although see Schmidt 2010). S/he shares this precarious liminal status with other expatriates, bohemians and mystics; mutants whose artifice flourishes in alternative enclaves where liberties sought are as multiple as the oppressive conditions in the lifeworlds from which they have made exodus. Seasons in Goa echoed a diversity of intent, and a concomitant medley of experience. There were those who simply underwent a decadent wasting of their selves in orgiastic abandonment at year's end. This predictable annihilation of familiarity is typical to the turn of the year, where New Year's Eve is among the pinnacle celebrations in the lives of Westerners, with this transit featuring prominently among those vacating in Goa. Here paradisical Goa, perhaps now more than ever, might be considered in the light of the "zone of indistinction between the human and the animal" (Agamben 1998: 105) that Diken and Laustsen argue characterizes tourist "camps" of naked excess and licensed transgression like Ibiza, the clubbers paradise defined by dance music, cheap drugs and casual sex (2004: 2). By comparison to the seasonal trippers as ravenous homo sacer making camp with no thought for tomorrow, others sought expatriation from Occidental subjectivity in an enduring career of seekership, or channeled their insouciance into projects fueling the Goa "state of mind" (Elliott 2010) shipped to 
regions outside Goa, sometimes remaining true to principles that attracted exiles in the beginning, other times reinhabiting modes of practice once abhorred. A prominent figure among the cultural fugitives and antinomians who made it to Goa, and then made "Goa" a cultural phenomenon beyond "the beach", Gil is a liminal exemplar whose heteroclite dharma-punk rhetoric has been eulogized and excoriated in equivalent intensity.

Gil is foremost an exponent of ritual transition, who professes to adopt the trance dance assemblage as a revitalizing spiritual technology. His millenarian repertoire is consequent to the intentional ritualization inhering in Goa trance and inherited by psychedelic trance. These reflexive practices appropriate and repurpose functional elements of dance/music events throughout recorded history, European and otherwise. Such practices absorb the semiotic cachet of traditional ritual sampled and remixed by producers, and under this romanticism, Goa is seen, at least in Bizzell's (2008: 288) distant gaze, as "a screen upon which to project the desires and utopian fantasies of a Western generation in the midst of a spiritual and ontological crisis". In Gil's rhetoric, ritual practice is appropriated and remixed from a generally unidentified primordial stock to which we are all apparently heirs. Gil, whose repeated mantra is "redefining ancient ritual for the $21^{\text {st }}$ century", ${ }^{3}$ has his thoughts sampled on Lalith K. Rao's (aka Alien Mental) track "Ritual” (Mind Hack, 2007):

I think that my concept can fit with every culture because it draws inspiration and direction from a time of humanity when, no matter where you went, people were in touch with the earth and the spirits of nature, the Sun and the Moon and all the elements. And so we're delving to the same place and trying to bring the same thing forth but with the technology of the $21^{\text {st }}$ century, and in a way to appeal to the youth of the $21^{\text {st }}$ century.

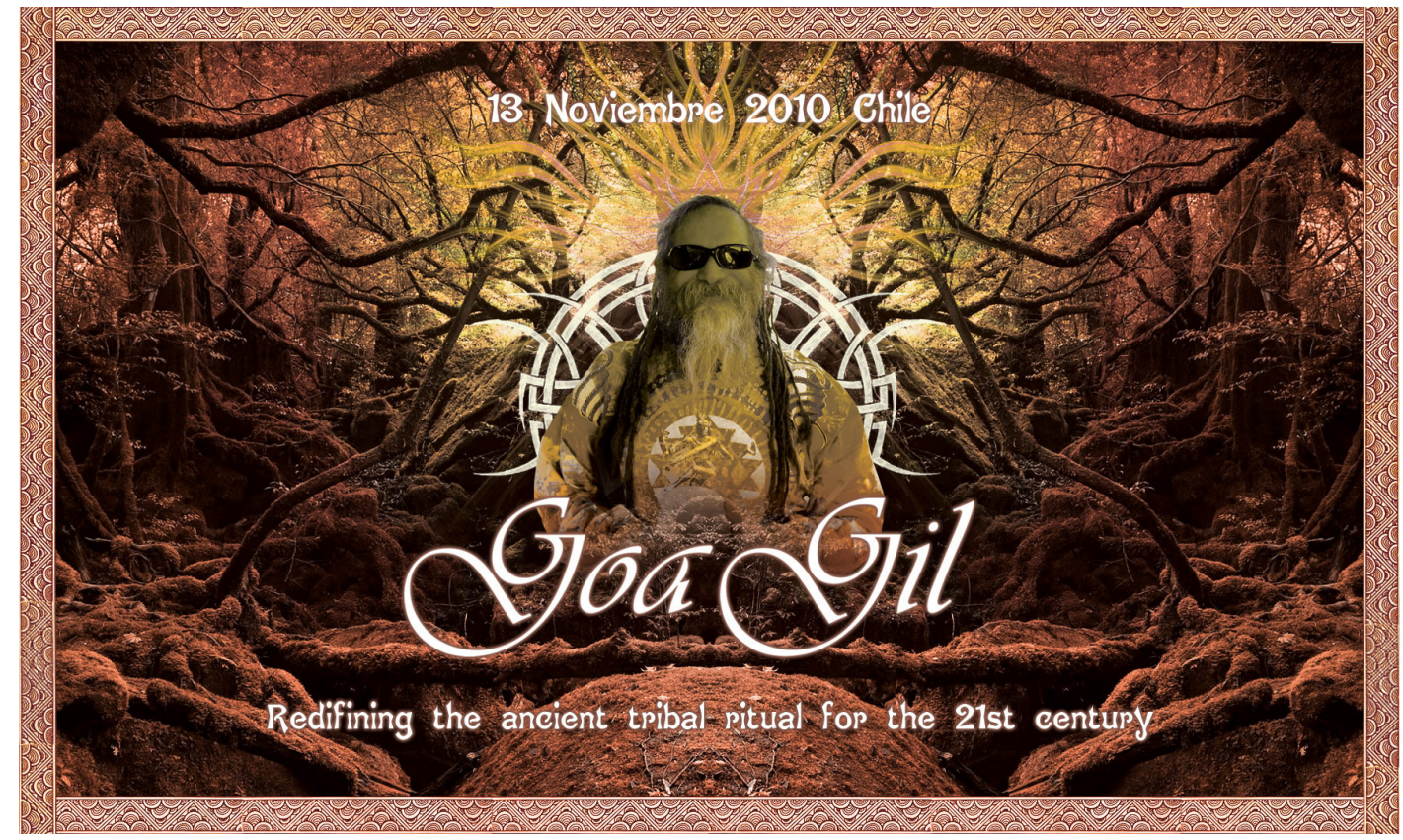

Figure 2. Poster for Goa Gil party, Chile, 13 November 2010. 


\section{Goa, Gil and Trance}

ANJUNA, GOA, provided the beach setting for spontaneous hippy dance and music manifests since about 1968, with Anjuna, Calangute and Vagator beaches host to ecstatic dance gatherings from the early 1970s. Many acknowledge the important role of the "original freak", the magnetic jazz bassist and existentialist writer Eight Finger Eddie as an instigator of this scene. Making a notable break from the prison with imperceptible bars known as "life" in the United States, and drawing others to his unique style of unpretentious enlightenment, Eddie arrived in Goa in 1966 where he rented a house (which eventually became Vince's Bar) on Colva Beach, and later had a free house on Vagator Beach. ${ }^{4}$ It was Eddie whom Gil arrived looking for in 1970. Gil (who was widely known as "Goa Gil" by the late 1980s) departed San Francisco in 1969, where he'd been involved with Chet Helm's Family Dog collective and had travelled with the early Sons of Champlin rock band as a roadie, before heading to Amsterdam, and subsequently taking the overland route to Goa. As Jeff 604 (n.d.) recalls, between November and April (winter; i.e. the party season) through the 1970s, Eastern-trekking hippies would rendezvous at the beach paradise at which Eddie had already become well known. Arriving overland, with many enduring hardships and ordeals or otherwise encountering epiphanies and life-changing experiences at spectacular junctures along the "hippie trail", Goa was cherished as an off-world paradise for travellers, a place where arrivals could share stories with fellow freaks, long before expatriation became a packaged tour-option and "raving" a desirable experiential commodity for foreign and domestic tourists alike.

As former Anjuna resident and co-founder of California's Turtle Creek Sanctuary Swami Chaitanya explained, being a "psychonaut", an explorer on "the frontiers of consciousness", was the logical option for cultural exiles of the 1960s unable to physically travel further west having obtained the edge of continental North America. According to Chaitanya, who first travelled to India in 1970 working as a cameraman shooting the Fred Cohn filmdocumentary about Hindu holy men Sunseed (1973), and later, as an initiate of Inana yoga, Raja yoga and Sri Vidya, became himself a holyman and a recognized presence at Goa and psychedelic trance gatherings, "we thought we were going to places that people hadn't gone before, and that was for many of us the higher purpose of the trip.". When Gil arrived in Goa, there were ad hoc parties over the Christmas and New Year period where hippies strummed acoustic guitars, played flute, hand-drums and sung around campfires on the beach. Gil himself played a repertoire of his own original songs, including "God's Children Are Everywhere" (which was written en route to India in 1969), "Song To Krishna" and "Welcome In The Dawn Of The New Day", on his acoustic guitar in the period before electricity came to Anjuna (1975).

While the scene was originally acoustic, even prior to the arrival of electricity, car and bike batteries and generators were used to power small house sound systems. Gil recalls that it was during the 1973-74 season that he first DJed playing tape cassettes "off the porch of some house" in Anjuna and then, in the following season (1974-75), played on Anjuna 


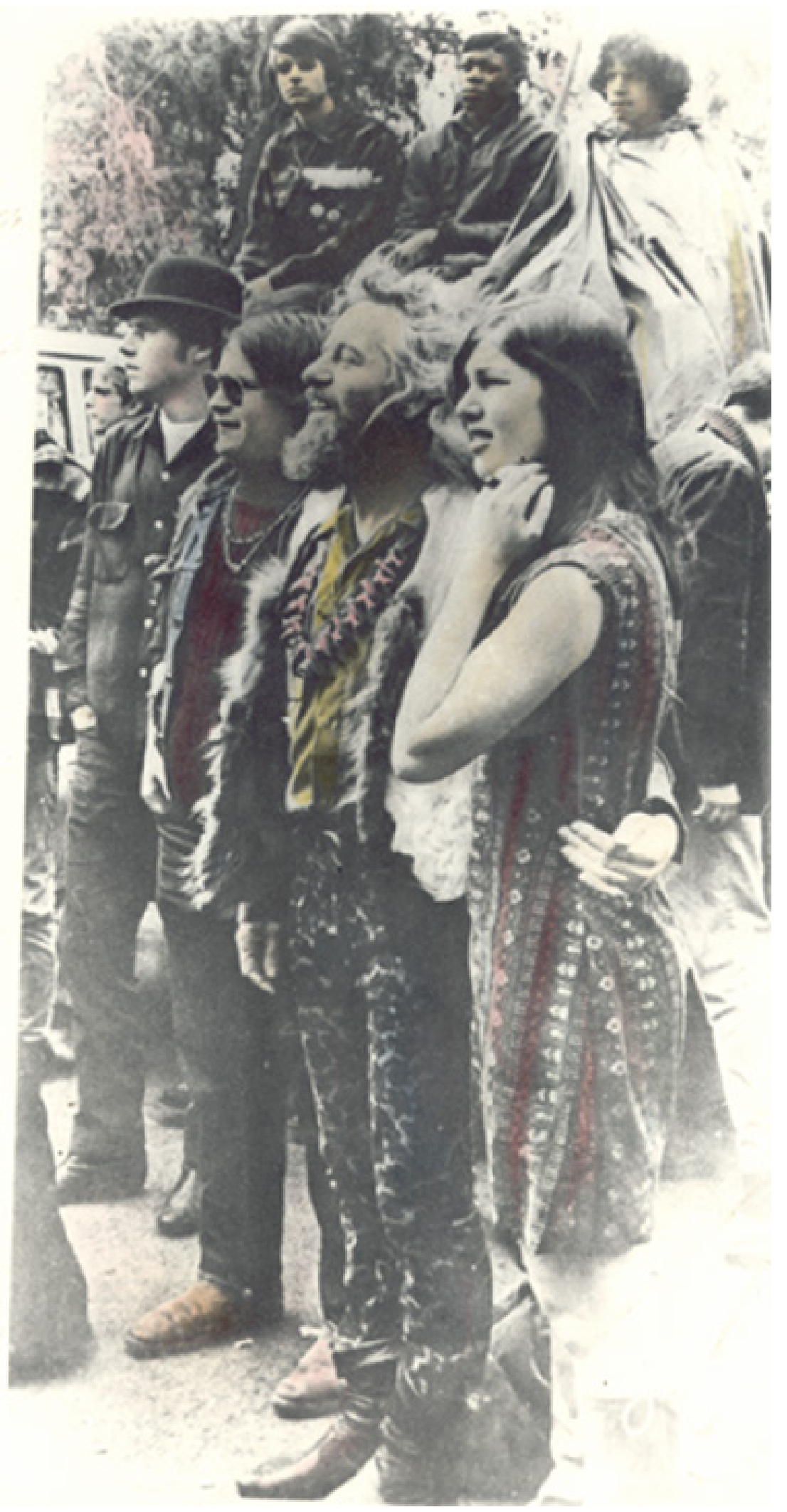

Figure 3. Gil, Acid Eric and Friends at a Love-In in San Francisco in 1967. Photo: Goa Gil 
beach after the flea market on a "little Fender PA system with generator owned by a friend". It was in 1973-74 too that Malcolm and Davina showed up in their bus having exited the UK hauling Marshall amps and other equipment gifted by Pete Townsend. ${ }^{6}$ According to English-Australian Steve "Madras" Devas, the "band's worth of gear" with which they departed England had dwindled to a single amp over the long passage to Anjuna Beach via en eventful stopover in Kabul, ${ }^{7}$ although in Gil's recollections the equipment included a couple of loudspeakers that had been The Who's monitor speakers. Regardless of what equipment survived the journey, subsequent rumours that The Who played Goa were rife. Gil recalls that this system provided the sound for the "Teenage Wasteland" parties in middle Anjuna beach in 1973-74, adding that these were "possibly some of the first parties where music on tapes was played at the beach on amplified speakers". ${ }^{8}$ In this period, Gil carried a suitcase loaded with an arsenal of cassette tapes, a collection which included not only the psychedelic rock of The Beatles, The Rolling Stones, Jimi Hendrix, Santana, The Grateful Dead and all the bands of the San Francisco Sound, but "soul classics that I had grown up with like Otis Redding, James Brown, Ike and Tina Turner, Bobby Blue Bland, Chuck Berry, Little Richard etc etc etc as well as many other styles like the Jazz of John Coltrane, Miles Davis, and others, sometimes Blues, Rhythm \& Blues, and even Reefer songs from the 40s". "Gil was thus already one of Goa's proto-selectors in a period where he, as he informed me, "started to try to use music to create a story or storyline, reflecting the world, the things we were experiencing, and the times we were living in". ${ }^{10}$

Throughout the early 1970s, spontaneous dance jams on the beach were evolving into the regular Full Moon gatherings. While this is a story this article can only broach, the involvement of Steve Devas is crucial since, in his own assessment to me, he "founded the Goa live band music scene on Anjuna beach on 10 November 1974" after returning from the Tsang Fook Music Store in Hong Kong (and successfully negotiating customs at Bombay Airport) with "two Stratocasters, Fender bass guitar, two Fender amps, bass amp, mics and bits and pieces". The equipment was taken to the stage at south Anjuna beach for "the first live party". Devas continues:

Friends and well wishers built the stage, others donated a keyboard and drum kit and then, as if by magic, amazing musicians appeared and Anjuna began its passionate love affair with serenading the stars and dancing wildly under the moonlight. For three seasons I managed the rock and roll bands that played on full moons and at other parties, including, in March 1975, a memorable gig at the Goa Carnival in honour of King Momo. With some good friends, I rented a large Goan Portuguese mansion at the back of Anjuna where I kept the music gear and this, the 'Italian House', was the first Music House. We jammed and had some rehearsals there but for the most part all the parties were on the beach. ${ }^{11}$

At this time, Gil co-wrote original work, played guitar and performed vocals for the freak ensemble The Anjuna Jam Band, and later played bass in The Big Dipper band, which was, according to Devas, "the longest running and arguably most successful Goa hippy band to 
come out of the seventies music scene.... It lasted all through Gil's tenure of party manager and music house operator". While this was "decent rock 'n roll," 12 Devas remarked that "the dancing and parties reached sublime heights never seen again" when the funky French rock trio he dubbed "Patrick \& Co" appeared in the 1974-75 season. ${ }^{13}$ By 1976, Anjuna was becoming a thriving seasonal freak music scene. In March 1977, Devas sold the equipment to Gil who kept it in a house near Chopora which was also dubbed the "Music House". In this new "Music House", musicians, stated Gil, "could meet other musicians, form proper bands, and have a place to rehearse". ${ }^{14}$ At this time, Gil travelled back to the US and returned with "a proper stereo PA mixer with multiple inputs, guitar and bass stings, drumsticks, microphones, effects units, tubes for the amplifiers" and other accessories required to maintain a live music scene. He had a large PA built by a sound technician in Bombay, and built another stage on the beach at South Anjuna. The period between 1977 through 1980 "became very organised with live bands, djs between the bands, parties every saturday at the music house, and full moons, christmas and new years at our stage on the beach". ${ }^{15}$

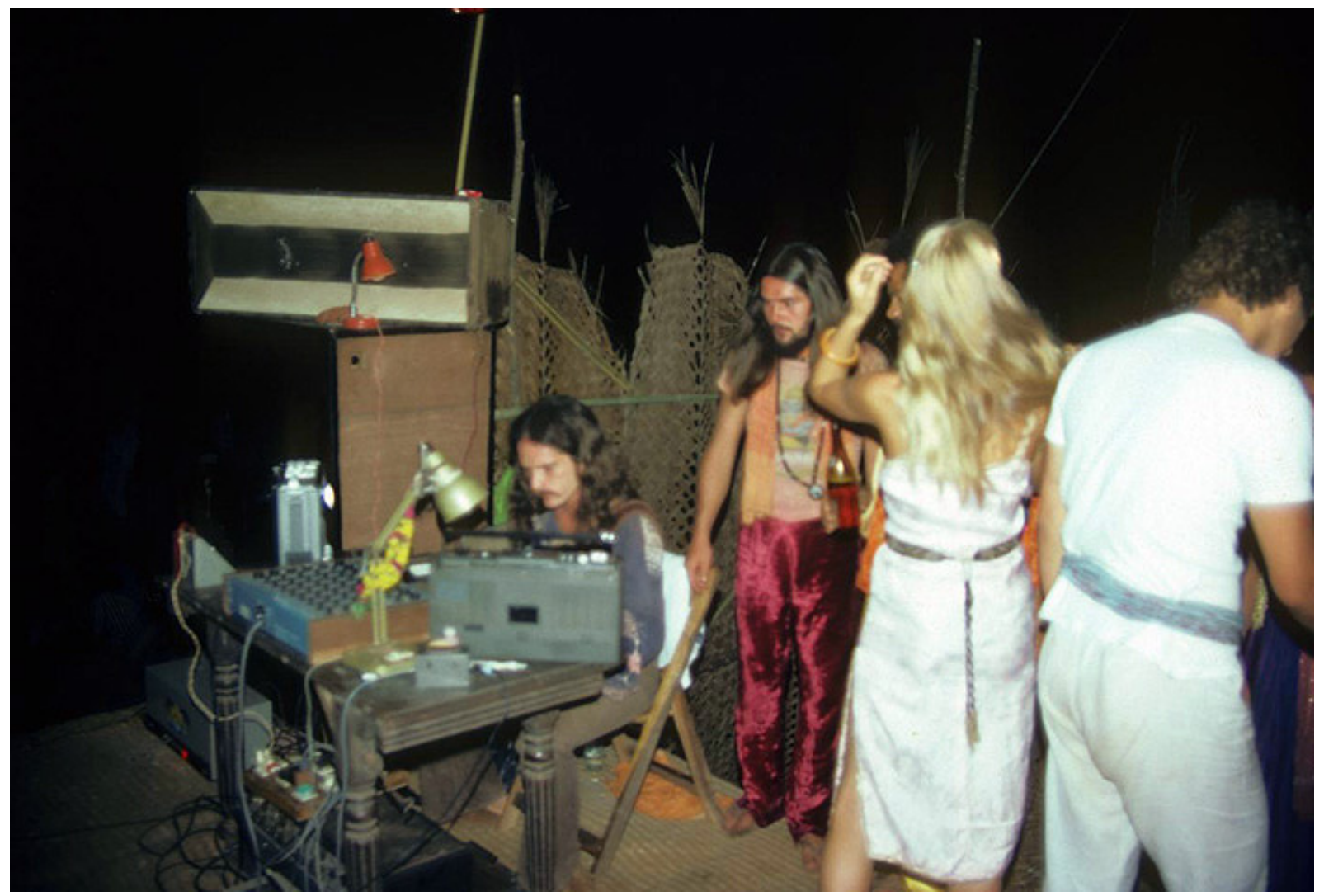

Figure 4. Goa Gil DJing on tape recorder between the bands, 1977-78. Photo: Gilbert Garcia.

Impressed by the scene's live psychedelic “jam band" environment, Austrian Peter Ziegelmeier stated that "we jammed all night to break away from the three minute pop 
song”. Ziegelmeier had studied musicology at Banaras University, Varanasi, from 19721974, learned the sarod (a stringed instrument) and later formed (with Hans Schiller) the techno-trance outfit Kode IV (in which Gil and Ariane would contribute). He was part of an expat milieu of artists who seasonally commuted between Goa and European cosmopolises where they were exposed to underground scenes and sounds, developing tape cut-up techniques deleting lyrics obsessed with "whether the girl likes me or dislikes me", with the deliberate omission of signifiers of attachment and desire better enabling the expansion of consciousness. ${ }^{16}$ These frontier editors created "special mix" tapes using obscure material spliced from the B-sides of diverse 12-inch records, performing and remixing these mixes in an evolving environment of creative exchange. Spokespersons from the period recall the sheer diversity of music being played in Goa, and it was an environment in which the DJ, as a seasoned carrier of fresh and diverse sound would gain prominence (over the band). At first playing from cassette, then digital audio tape (DAT) and later CD—though not vinyl since records warped in the heat and proved difficult to transport-DJing would become the prominent mode of performance in Goa. Under pressures to perform all through the night, perhaps several nights a week, in a remote region, DJing proved to be the most costeffective and efficient technique of performance delivery. Instruments like drum kits were onerous and expensive to transport, and the stamina of band members waned well before sunrise. As had been discovered in Jamaica and in the proto-discos of New York at the turn of the 1970s, powered machines under the control of the autonomous DJ, or team of DJs, proved to be the perfect devices to sustain the all-night party (together with an assortment of psychoactive substances).

By the 1980s, the parties had expanded in size as a reflection of the growing numbers of foreign visitors to Goa: increasing from 17,234 arrivals in 1977 to 33,430 in 1980 and 97,533 in 1986, over which period a younger traveller population imported new stylistic identifications, including punk, reggae and soul (Elliott 2010: 30). As this expat party enclave was infused with rapid developments in electronic music production and performance in the 1980s, a "Goa" sound emerged, the eclecticism of which held comparison with the Balearic sound of Ibiza. Australian DJ Fred Disko recalls spectacular beach-front conflagrations with, according to his estimate, "5,000 people on acid" (in Devas 2010a). While the accuracy of this statement may be called into question, as Auckland-based DJ, astrologer and documentary film-maker Ray Castle remembers, there was "a copious supply of acid and other hallucinogens always free at most parties" (in ENRG 2001: 253). A DJ of early funk, disco, ska and industrial rock in the late 1970s/early 1980s Auckland, who first landed in Goa in 1987 where he began DJing in 1989, partnering with Gil over the 1991 season (i.e. between January and April 1991), Castle is integral to this story.

As the 1970s came to a close, the birthing cries of a new dance music movement (and the death throes of the old) were heard in the music of Tangerine Dream, Kraftwerk and Yellow Magic Orchestra drifting across the beaches of Goa. But while there was always keen reception to ambient electronica within this scene (remaining so throughout the psychedelic trance development), what was decried as "techno" was met with resistance as older freaks poured scorn on the new electronic sounds. In an interview for the documentary 


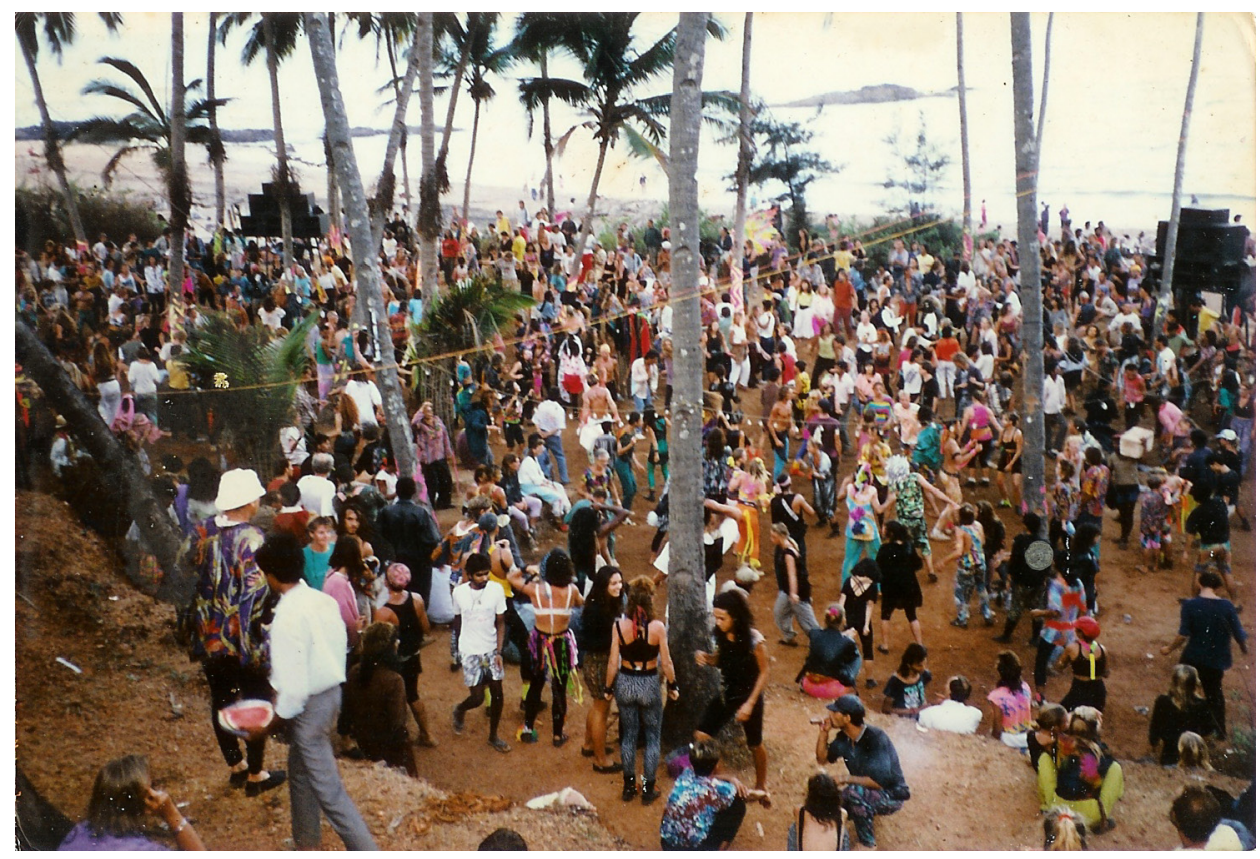

Figure 5. Party at South Anjuna Beach, 1991. Photo: Goa Gil.

project Goa Hippy Tribe (a 30-year Facebook-enabled reunion of Goa freaks directed by his son Darius), Steve Devas was clear that "something changed". From around 1978, younger freaks returning from European summers in the underground disco scenes of Berlin, London, Paris and elsewhere, brought back these new mixed sounds. "A whole group of new people. They brought out new amplifiers. Very powerful amplifiers. So they set up a party and they had the best equipment, and they had all this music, which seemed to flip from the high hippie music to techno" (in Devas 2010b). Devas recalled the "defining moment". It happened around the turn of the 1980s. A gentle hippie known as "Homeopathic Peter" gained sudden fame on the beach when word went round that he'd "punched out" a Canadian DJ, a financier known as Dr Bobby, at a private house party in Calangute. The Canadian had a powerful amplifier and was "instrumental in setting up these new parties". For Devas, this incident provided the soundtrack for "the end.... It was a loss. The music lost some essence of what hippyism was about" (in Devas 2010b). In his correspondence with me, the period is identified by Devas as "a coup d'etat. A musical putsch by the noir partyites. Lyrical hippyism was dead in the water. It left no traces". He gave no quarter: "techno music and these deejays were a disaster for the beach". ${ }^{17}$ Of course, Gil and Castle, who later rode the crest of this eclectic-electric tsunami, held different views. Though he would himself become a vociferous critic of the "fundamentalist psytrance" of the 1990s which saw the codification of unregimented psychedelia into a "deity enshrined product" with "strict aesthetic rules", Castle relays a story from the 1981-82 season, when Fred Disko DJed Goa "disco parties". Though Castle wasn't present, he is reminded of the reaction to Dylan when he went electric: "All the hardcore Anjuna traditional hippies rebelled and 
freaked and tried to prevent them playing techno, disco and saying 'this is not psychedelic, this is not the real thing man. We're into psychedelic rock and its gotta be live music'. And they actually attacked the sound system and stopped DJs like Fred Disko". ${ }^{18}$ For Devas, who was at the front lines of this cultural standoff, such a narrative affords those he regarded as "techno-tyrants", and "ego fuelled late-night cocaine swingers with no interest in what the audience wanted", ${ }^{19}$ with an undeserving heroism.

Castle passed comment on another figure involved in this debacle-Goa Gil, who, he says, "was one of the people who blocked or resisted the techno" which, Castle figured, stole attention from Gil's band. ${ }^{20}$ Lamenting the loss of an authentic "live" music scene, Devas stated that "after Gil sold the equipment, there was no longer a live music scene in Goa with the original hippy generation. The parties turned to psy, doof, techno etc, but that's another story". ${ }^{21}$ But this was a story in which Gil, who grew interested in electronic body music $(\mathrm{EBM})$ and recognized where the crowds were headed, would become engaged. Indeed, although met with considerable antagonism from his freak rock brethren, Gil spanned a bridge across this cultural and generational chasm. During the 1983-84 season, the newly arrived Frenchman Laurent teamed up with Fred Disko, and with Swiss Rudi, Gil and others, performed all-night sets laying down an explosive mix of new sounds, including the first European post-punk experimental music, the Neue Deutsche Welle, and EBM acts like Front 242, Nitzer Ebb and Canadian industrial outfit Skinny Puppy. Soon synth-pop, electro, new beat and Italo-disco styles were worked into the mix of this DJ-led scene. By 1986, the music played at parties on the shores of the Arabian Sea and in the jungle hinterlands was exclusively electronic. By the end of the decade, under the influence of the Frankfurt techno-trance sound, Detroit techno and acid house from Chicago (Rietveld 2010: 75), there were seasonal anthems, notably The KLF's “What Time is Love?” (1988). But it was in the early 1990s that the first "Goa" tracks began circulating, such as Jungle High's (Johann Bley and Ben Watkins) "Jungle High" on their self-titled release (1992). At this time, artists of various styles (from punk to techno and hard trance) inspired by the Goa experience were producing material with long instrumental or ambient sections allowing for easier mixing (using DAT players). Notably, various mixes of The Overlords' "Sundown" (Sundown, 1991) featured the crashing surf at either end of the track. From the mid-1980s, pioneer DJs had been exporting the Goa vibe to various locations, including Ibiza, which had been a constant site of absorption/innovation (D'Andea 2007). Fred Disko threw parties in Nepal in 1985 and Thailand in 1987 (see Cole and Hannan 1997), and with friends from Goa, Ray Castle held the first Pagan Production party at Ruigoord, Amsterdam, in 1988, and again in 1990 and 1991, parties which he claims were "the first Goa style parties in Europe". 22 In 1988, Gil started formulating his ritual in northern California, where a hardcore fan-base grew.

\section{Altared States}

In AN INTERVIEW with Freeze Magazine in 2001, Gil offered the often-repeated view that "the party is Holy! It is the Old Time Religion", and that "since the beginning of time 


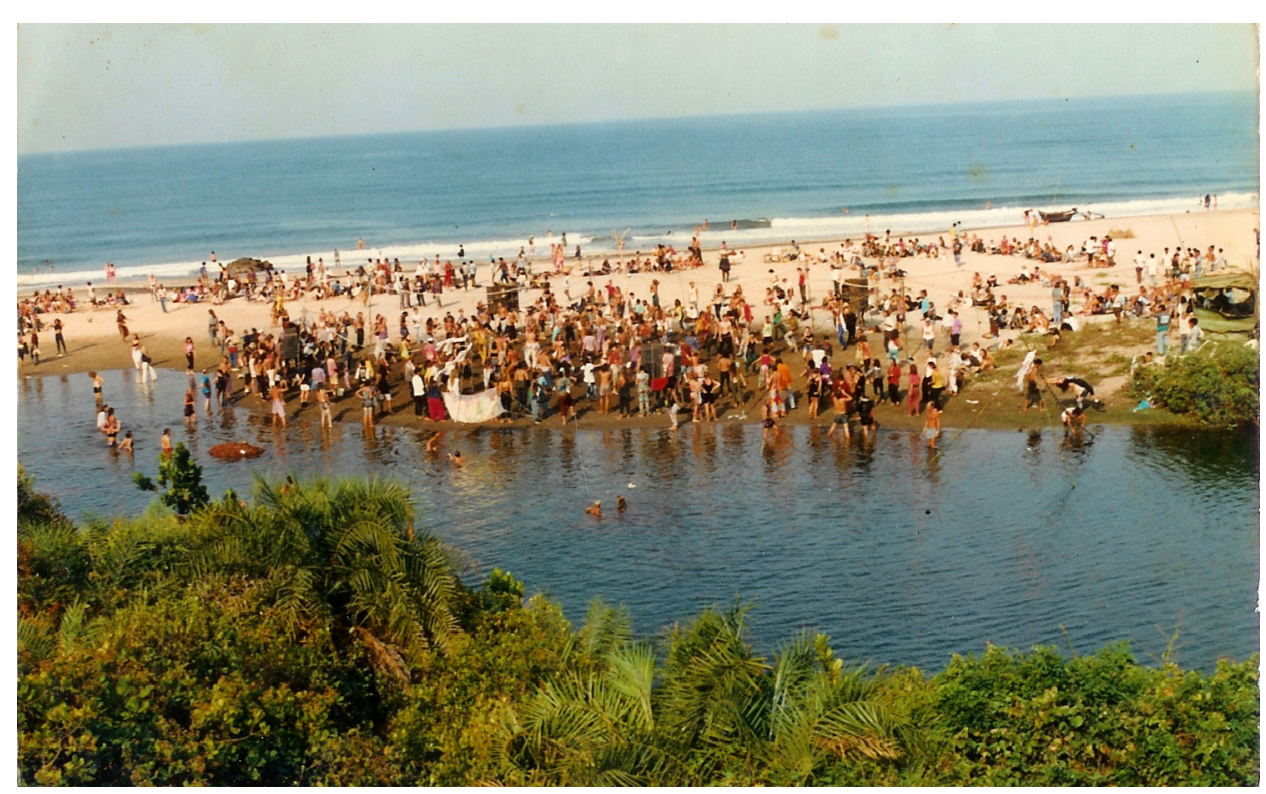

Figure 6. Party at Arambol, 1991. Рhoto: Goa Gil.

mankind has used music and dance to commune with the Spirit of Nature and the Spirit of the Universe". Within the Goa trance dance which Gil fashions as a "ritual" more than a "party", "we go beyond thought, beyond mind, and beyond our own individuality, become One in the Divine Ecstasy of union with the Cosmic Spirit". Under Gil's guidance, dance ecstasy is purposeful, initiatory. For Gil, and his many followers the world over, dance is regarded as a technique of "active meditation", enabling actors to access the divine truth, revealing their own relationship with the cosmos (Freeze Magazine 2001). Interviewed by McAteer (2002: 47), Gil stated that as an outcome of this experience it becomes evident that "all life forms are existing from this Spirit, and, you know, we're a part of that thing and we have to protect that thing". In an echo of perennial mystical idealism, the trance dance experience is fantasised to assist participants to "become more sensitive and aware of themselves, their surroundings, the crossroads of humanity and the needs of the planet. With that awareness comes understanding and compassion. That is the need of the hour and the true Goa Spirit".

While the mission he took on the road in the 1990s has appealed to a great many, Gil has been spurned by spiritual anarchists and secular minded antagonists alike. At his events, it is not uncommon for devotees to set up altars at the front of the dance floor, which grow over the course of the event as dancers smudge sage and place candles, flowers and other offerings. With the entire dance floor facing Gil overnight, as McAteer (2002: 51) notes, Gil is himself an "enshrined object". It is an intriguing circumstance in a culture with antinomian roots. On the one hand, so enshrined, Gil may embody ego-dissolution, the guru who through his shaktipat ${ }^{23}$ and the jungle of symbols in which he is nested, guides dancers into the condition of samad $\bar{a} h i,{ }^{24}$ provided they make the sacrifice (of their egos). He may then be a pure exemplar of the neo-mystical union with the "cosmic spirit" which, the 
further Gil travels from the Goa vibe of the 1970s/'80s/'90s, becomes an object of intrigue among urban psytrance participants for whom Gil acts as a kind of yogic mascot, a redeemer for their own psychedelic praxis. On the other, he may rather be an icon of ego-inflation and self-aggrandizement, a view not uncommon among those who point out that Gil refuses to perform with other artists or play at festivals where he must share the limelight with other DJs with whom he must compete for the sacrificial attentions of event-goers. From this perspective, Gil stands out not as a flattened ego but as an inflated persona. For those who are warmer to the anarcho-shamanism of "psychonaut" Terence McKenna-whose wisdom has arguably penetrated psytrance more that any other individual (judging by the voice samples found in productions)-Gil's methods constitute a comparatively ecclesiastical route to cosmic consciousness. Goa Gil's roadshow is an incongruous circumstance in a scene which emerged pursuing a communitarian ethos and is ridiculed by those who've little truck with authorities, be they political, religious or celebrity.

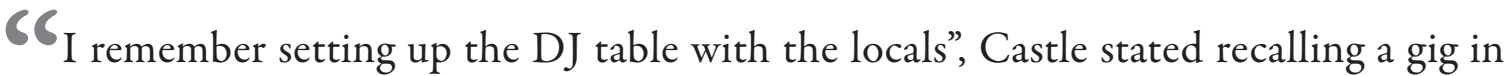
Anjuna in the 1991 season. "I had it tucked away by the palm tree out of the way, and Gil said 'Oh no, it's got to be over here so everybody can see us". Castle does not shy from phrases like "priest", "megalomaniac" and "tyrannical" when it comes to describing Gil, and all in one flourish. Articulating his grievances further, Castle measures Gil as "a clever mystical cabaret act. ... He has basically cast himself as a sort of messiah prophet using Goa and his music to propagate and proselytize his own agenda as a cult leader. It's just entertainment in the end.... It's great theatre, dramatising and mytho-characterising himself within the context of India and the hippie romanticism of Goa". ${ }^{25}$ Furthermore, "full of hierarchical hubris .... the Ram Das of techno" is charged to have contradicted what Goa was once about: a "feeling of collectivism, of family, shared resources, where people would exchange music, and different DJs would play parties and play together". But where the theatre of the dance floor was once central, in the 1990s "Goa trance" became a vehicle for "celebrity DJs", artist as brand names projecting "an aura of personality", a process which Castle sees replicating standard music industry practices where the artist becomes the "product", where "everybody's facing the same direction", and giving their energy to inflated stage personalities. Pursuing an ostentatious and largely solo ${ }^{26}$ act in a scene with countercultural roots, Gil is considered to be symptomatic of this trajectory. Castle added that, although he collected great music in the early 1990s, Gil was "never popular in Goa, as a DJ". By contrast to the spectacle of Goa Gil, who has been scorned for possessing questionable mixing skills, the uncompromising Castle holds respect for Laurent, the lionized Frenchman who DJed in Goa from 1984-93, who Gil "saddled up" (DJed) with for the 1992 season (and with whom he remains good friends) and whose skillful cut-ups and mixes of EBM, new beat, electro, Italo-disco and Hi-NRG and other sounds on pitch-controlled Sony Walkman Professional WM-D6Cs shaped the sound of Goa. 


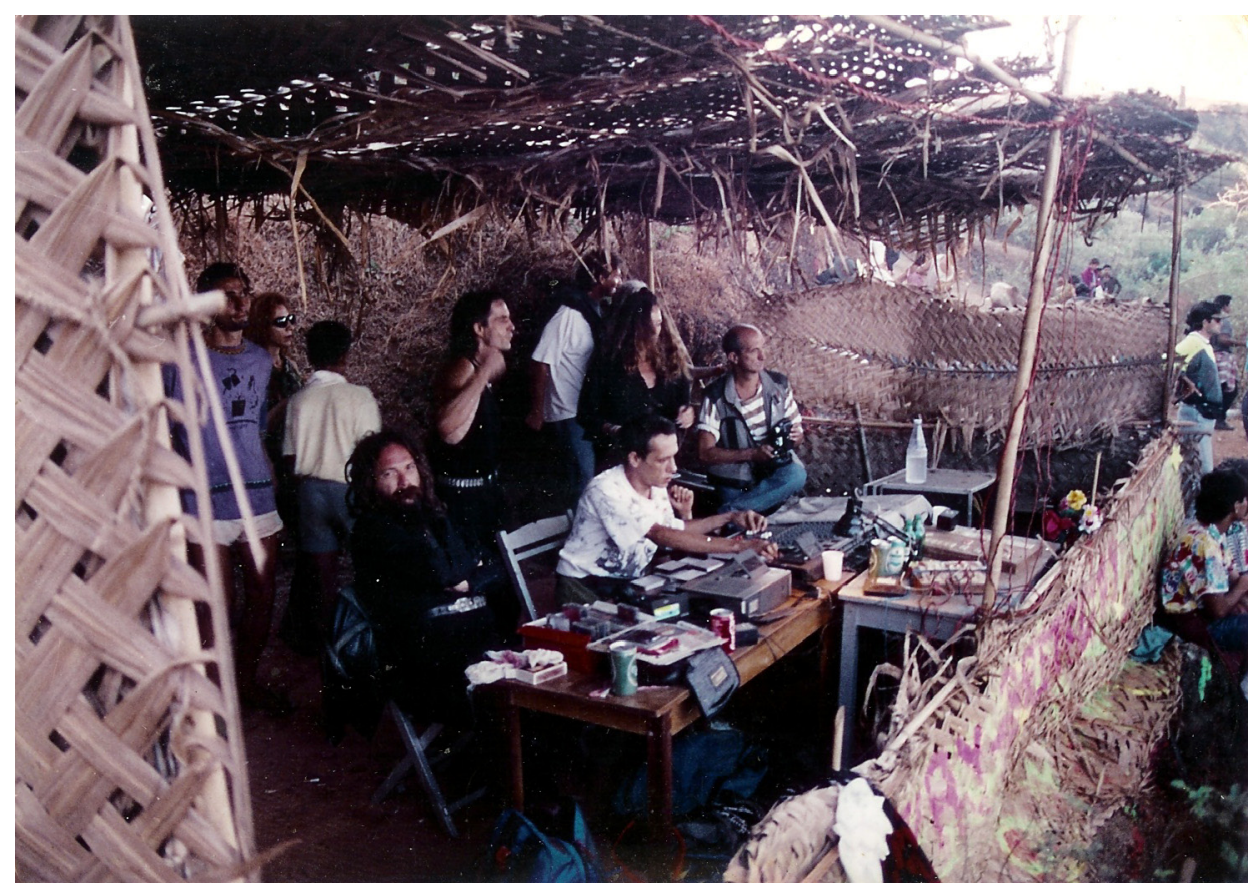

Figure 7. Gil and Laurent at a party on South Anjuna Beach, 1991. Photo: Goa Gil.

\section{Spiritual and Cultural Exile}

NOT LONG AFTER ARRIVING IN GOA in 1970, Gil hitch-hiked south along the coast visiting temples and smoking chillum with sadhus, the Hindu term for mystic, which he called "the other guys who had long hair and smoked dope" (Time Wave Zero 2006). He soon travelled with a sadhu who took him to Puri, Calcutta, Benares, Delhi and finally Kashmir, where in the mountains at the age of 18 , he became disciple to Sri Swami Nirmalanand Saraswati Maharaj, a guru in the Shaivite order Juna Akhara. ${ }^{27}$ Eventually Gil became Swami Mangalanand Saraswati (Mangalanandji), and was subsequently recognized as a sadhu, and at the Haridwar Kumb Mela in 2010 was proclaimed Shri Mahant (Antahrashtriya Mandal ka Shri Mahant $)^{28}$ becoming one of the first foreigners to hold a seat at the Akhara Council, which oversees 200,000 sadhus.

The honorary title signifies recognition that, at least since the early 1990s (but possibly as far back as the 1970s), Gil has effectively channeled the yogic lessons of direct gurudisciple initiations celebrated to be rooted in the "enlightened source" Guru Dattatreya, 4,000 years ago (McAteer 2002: 25). An undercurrent of possibility among those exposed to yogic practice is that the next link in the chain could be... you. Gil points this out himself. While acknowledging that the constant travel associated with his professional lifestyle and religious duties renders it impossible to train disciples appropriately, "in some sense", he states, "many of the participants of my events are not only my fans but disciples". ${ }^{29}$ Gil understands that through his official role he is "programmed" to fulfill a divine "mission", to become "a pure instrument of God's will" (McAteer 2002: 96). This is intriguing enough, 


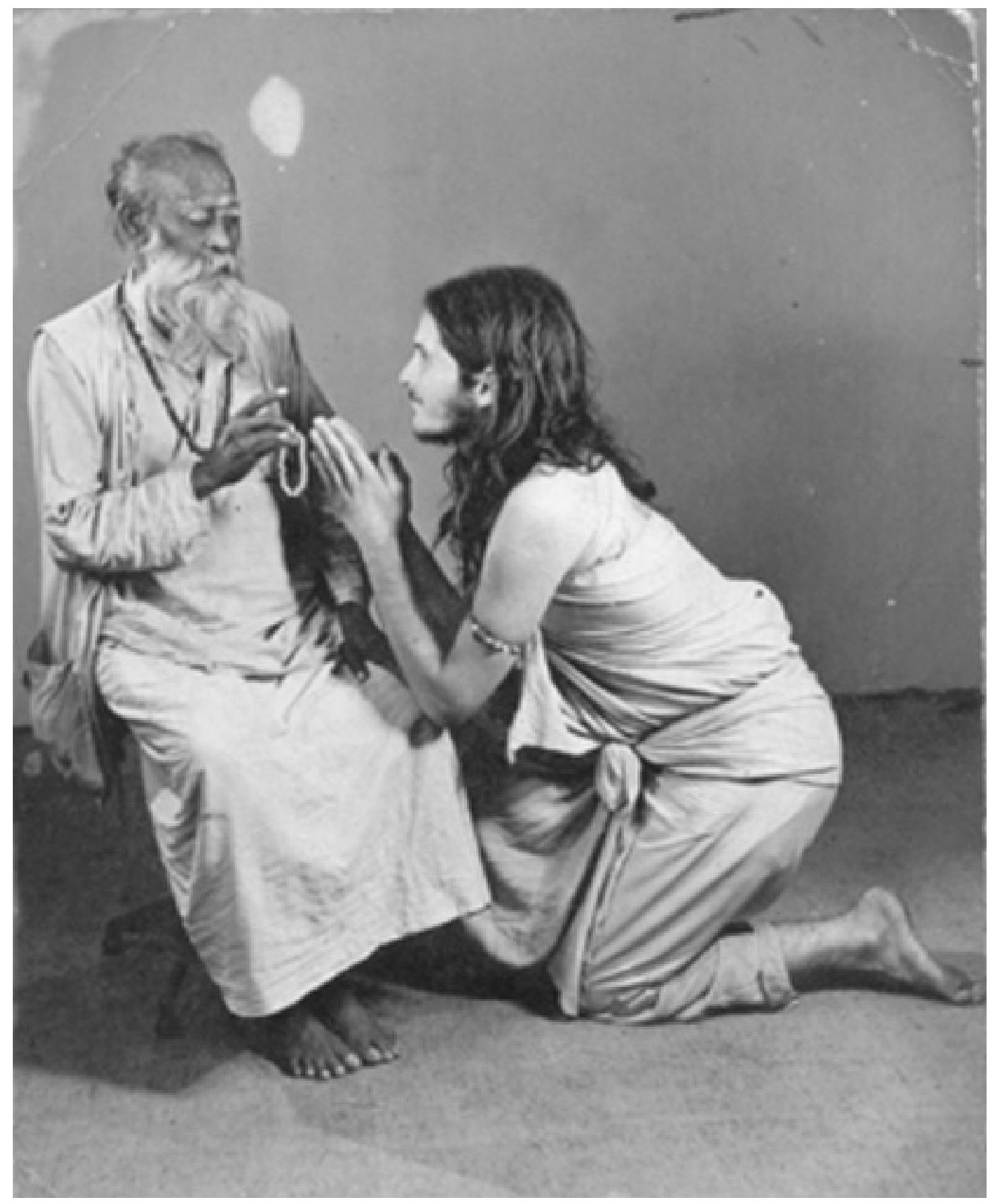

Figure 8. Mangalanand (Gil) With first guruji, Mahant Nirmalanand Saraswati Ji Maharaj, in Srinagar, Kashmir, July 1970. Photo: Goa Gil.

but Gil is not simply following a "duty" conferred upon him as a "pure" initiate of a sect (if that indeed can be called "simple"), but has been performing a role consistent with the approach of an artist-in-exile, a Californian rebel, whose anarchic dissidence and stage performance is sanctioned by his holy credentials. 


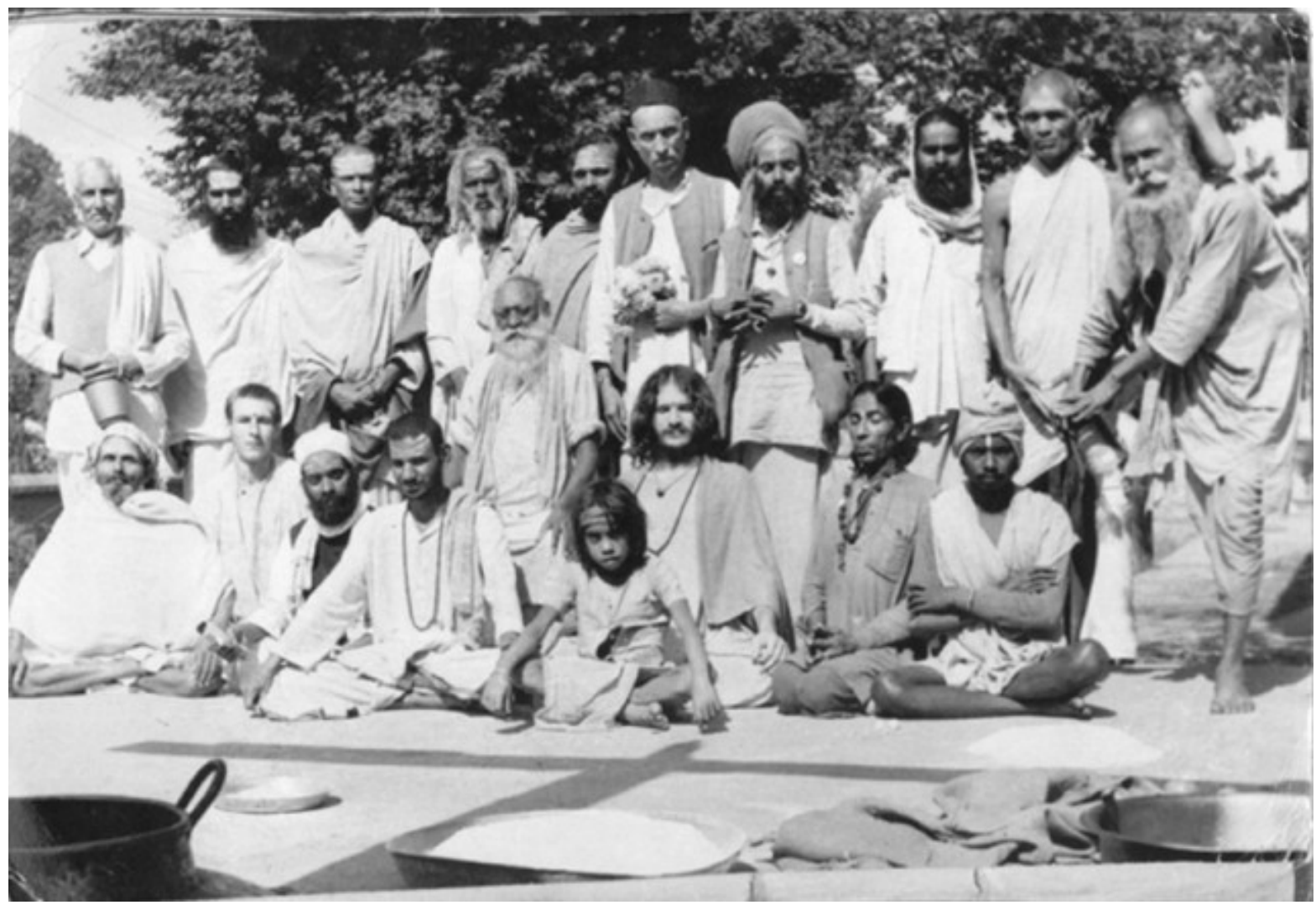

Figure 9. Gil with Guruji and Sadhu family at Ram Mandir, Srinagar, Kashmir 1972. Phото: Goa Gil.

For Gil, "art reflects the time and culture we exist in", ${ }^{30}$ nodding towards his embrace of the Kali Yuga, the last phase of the Hindu "Age of Conflicts". The theme holds correspondence with the emergence of the Goa movement, whose extreme freakish elements, ecstatic dance and radical connections with nature are expressive of the desire for revitalization and renewal in times of crisis long associated with Shaivite and Dionysian cults (Baldini 2010). Whatever valence we attribute to this interpretation, Goa trance grew as a movement uniquely responsive to its time. As Gil stated in a 1997 interview with Michael Gosney:

Sixty-nine, Nixon was President, Reagan was Governor of California, Altamont, Kent State. The negative side came down. They said 'we have to stop this thing'... So then many people decided, just with the timing, cosmic timing, many people from many different countries decided to split [from the West],. . . and headed for India on a spiritual journey, seeking spirituality and some sort of enlightenment. . . All these people who met overland became a kind of tribe. The jetset gypsies or the nomads (in Gosney 1997).

Between the 1960s and 1990s, Goa became a destination for cultural exiles, those "displaced peoples with displaced minds" (D'Andrea 2007: 9) who, following the promotions of Leary 
and the lead of Allen Ginsberg and Ram Das, were "dropping out", and even embracing a psychedelic manual to assist the process (Leary et al. 1964). Rather than mounting a direct confrontation, freak dissidents opposed to conditions in their homelands, abnegated, absconded and renounced, migrating to regions more conducive to their lifeways. Many of those who made Goa via the long overland route through Greece, Turkey, Iran and Afghanistan between 1969 and 1971 sensed World War III on the horizon. Following a popular emergent folk theory with its roots in the ideas of Aldous Huxley, many regarded psychedelic substances, especially LSD, as the antidote to nuclear annihilation. By the 1980s, Reagan was President and the arms race had escalated. Gil passes comment on that early 1980s climate in which he began formulating his ritual.

For me parties have always been a kind of reprogramming session ... so you just go with the beat, no matter what happens whether it's dark or light or it's the apocalypse. No matter what happens, you're just like dancing through it.... When these parties first started to happen and when that electronic body music was happening it was like nuclear disaster could have been around the corner and that was a big theme at that time ... it was like an apocalypse culture in a way. It looked like an apocalyptic event could be 20 minutes around the corner, and so through the dance, and through going through sound vibration and so many experiences and different pictures which came up in the mind through the course of going from the dark into the light we like to hope that ... it kind of helped us be prepared for anything that might happen and be able to deal with it (Time Wave Zero 2006).

As we'll find, the recurrent symbolic and symphonic visitation of the apocalypse is central to Gil's operation. While the effects of the Reagan Doctrine were being felt globally in the early 1980s, in the UK, the Thatcher Government had a devastating impact on England's free festival circuit, causing an exodus of cultural refugees throughout the decade. While Goa scholars and devotees may want to assign value to the Goa party as a sacred "ritual" experience (see McAteer 2002), or make vague connection with ancestral "tribes" whose roles enthusiasts believe they are fulfilling in the present, the expatriate cult of Goa was an outland-ish response to oppressive conditions in countries of origin, and indeed a statement on the human condition. This is what Gil means when stating that the Goa trance dance experience was always "more than just a disco under the coconut trees". As he stated, "We are using Trance Music and the Trance Dance Experience to set off a chain reaction in consciousness" (Freeze Magazine 2001).

Never exclusively hipster experimentalism, brazenfaced primitivism, nor reckless selfdemolition, Goa exiles sought alternatives to a world devoid of consciousness, to the alienation from nature deemed symptomatic of the modern era. Alert to the endemic crises of family and nation flaming domestic and international aggression, and to the disastrous impact of unchecked plundering of what had become recognized as the Earth's finite resources, this generation adopted a distrust for inherited religious, scientific, political and economic institutions. Some sought to annihilate their memories, national identities, 


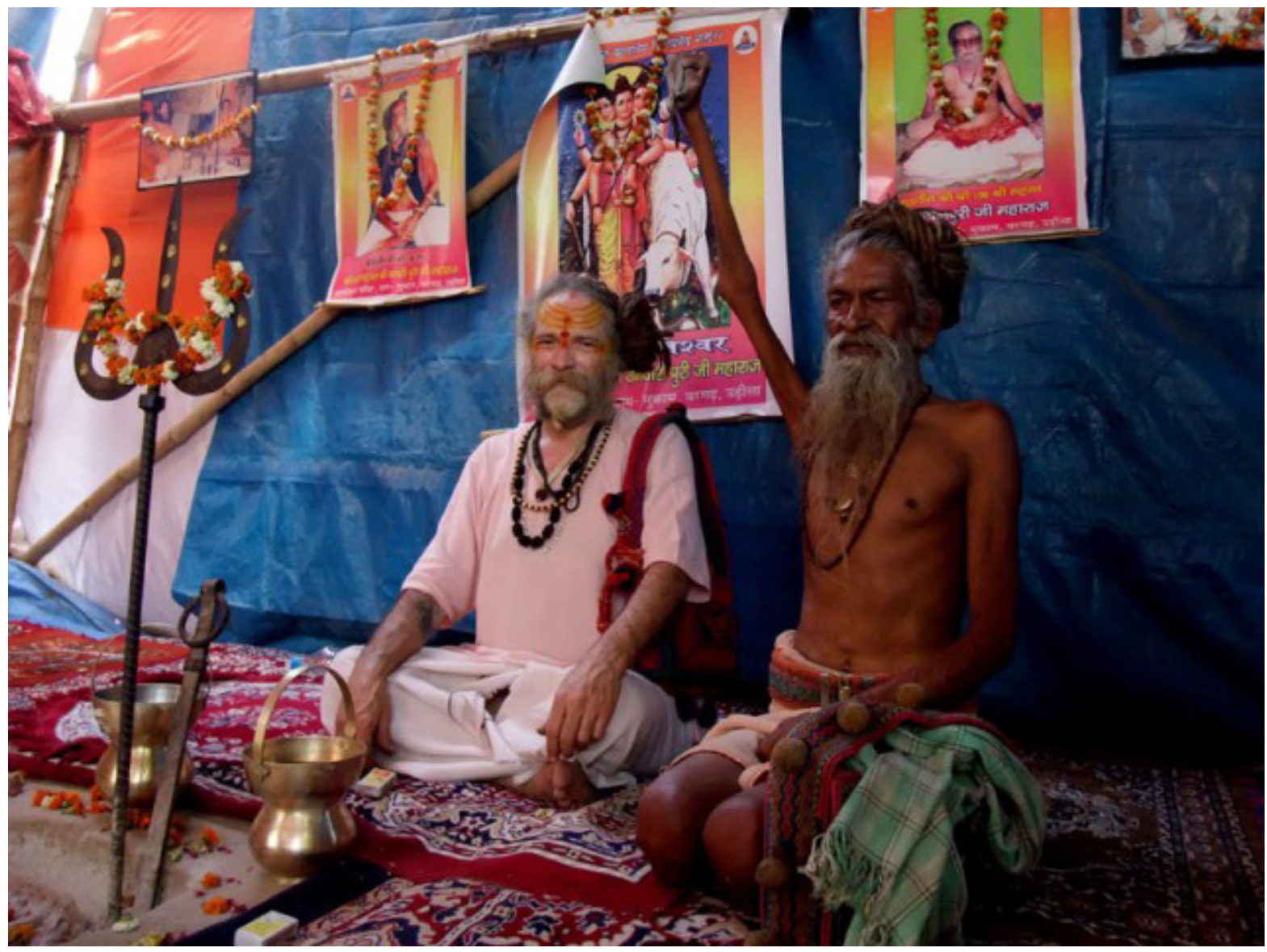

Figure 10. Goa Gil and Naga Baba Amar Bharti at the Kumbh Mela, Haridwar, India, 2010. PHOTO: GOA GIL.

biographies, in the reckless abuse of drugs, most tragically heroin, although charas might have helped too. Others became fixed on metamorphosing their "whole" identities. Adopting the view that change "starts within", or that one should "be the change you want to see in the world", many turned to healing arts, yoga, wellbeing and ecological practices designed to effect transformation of one's self and personal relationships as a prerequisite for making desirable changes in the world beyond. Dance, or trance dance, which is incorporated within, for example, the "dynamic meditation" practiced by the disciples (sannyasins) of Osho (Bhagwan Shree Rajneesh), was never far removed from the repertoire of therapies adopted in the quest for growth and responsible living. With the popularisation of LSD, the dance event developed the aesthetic of an epic journey, the experience replete with risks to the stability of conventional values and commitments, and enabling serious re-evaluations of one's life and relationships. Within optimized contexts, the experience enabled lasting connections with others/Otherness, and indeed facilitating, as many spokespersons have offered, a mystical experience. Existing art forms were modified and artifice invented to cultivate the experience, typically at a considerable remove from conventional society, with 
traveller enclaves becoming de rigueur settings. Under Gil's guidance, in Goa the party became an initiation ritual, an ostensible site of passage from spirit-less-ness and cosmic alienation, towards time-less-ness and cosmic union. A cavalcade of the outraged and the outrageous convened and committed to resolve the condition of separation through the mystical experience enabled by the trance party, which by the mid-1990s was developing an international reputation as artists who had been inspired by the Goa experience were importing its transposable "state of mind" back to their home countries in the form of "psychedelic trance" festivals such as Voov in Germany (started by Osho disciple Antaro), Boom in Portugal (initiated by Diogo Ruivo and Pedro Carvalho who met as children in Goa in the 1980s, see St John 2009b; St John and Baldini 2011, forthcoming) and Ozora in Hungary.

\section{Dark Yogi, Trance Dance and the Apocalypse Tao}

DRAMATISING CHALlengeS FACED, sacrifices made and lessons gained on the path to higher consciousness, Gil's epic journeys are in part shaped by the yogic practice integral to his own background. According to Gil, the "spiritual fight" is to go "beyond ego" and "realizing the self and the spirit" (in McAteer 2002: 94). It is with such a struggle in mind that he has committed to the trance dance event, where participants are exposed to egoshattering practice, from which nascent modes of identification are potentiated. In the context of overnight open-air events, the "death" of ego precipitates "rebirth". Indeed, the cycle of death/birth and the corresponding daily transit of the Moon/Sun through night/dawn are universal symbolic resources adopted to furnish initiatory experiences with meaning, and the Goa trance party is no exception. Most agree that the ideal party must be open to the stars, commencing before dusk and finishing after dawn. The passage from the closed recesses of the night into the open light of day provides a diurnal analogue for the yogic path to illumination-a path paved with perils and pitfalls for the wayfarer. Such is the experience of the generic initiate, who ordinarily suffers ordeals, faces tests and experiences fear and pain on the path towards obtaining a new post-liminal identity. Taking his cues from world initiatory ritual practice, "in the beginning" states Gil, "I play stuff just to get everybody dancing, and slowly, slowly it becomes more intense . . until like 5 o'clock, you know the last dark of the night, then it's like the apocalypse in one kind of way and very intense. And then when the light comes ... everyone's surrendered and become one with the dance and one with the vibe" (in McAteer 2002: 31). And so the trance ritual is structured to this end, often kicking off with a djembe jam with Ariane, who performs an hour "ethno/tribal" opening DJ set at most of his parties.

As noted earlier, Gil is an adherent of dark psychedelic trance, a field in which he would become established as a leading selector, and renowned for his "divine dozen", the name for his updated list of 12 favoured tracks and/or albums which he has posted on the internet since 1996 (and these days posted about three times a year). ${ }^{31} \mathrm{~A}$ decade downstream from the EBM explosion, Gil was surfing point-break on the dark wave, with proto-dark Goa producers and pacesetters like Germany's Xenomorph (Mark Petrick) and Russia's Parasense 
(Alexey Kurkin and Viktor Zolotarenko) looking on with interest and successfully gaining his attention. In Petrick's own assessment, "being the kind of traveller that he is, [Gil] was the only guy that you could listen to (in 1997) and not know $80 \%$ of the tracks he played, because the artists gave him the DATs in Goa and the record industry was lagging behind with the actual releases". Impressed by the marathon sets, Petrick recalls that Gil:

blew me away at that time and inspired me to change my style from the hardtrance 160 BPM stuff more in the direction of goa sound. When he played the next time in Berlin in 1996, i gave him a promo DAT that i named "Horror Trance" a term that was previously unheard of in the otherwise spiritually monolateral trance scene of that time. He liked the tracks a lot. One of them was "Obscure Spectre (Horror Trip Rmx)" and i think "Carnage Vision" was also on there. ${ }^{32}$

Indeed you can imagine Gil channeling Petrick's post-apocalyptic vision as he reeled out "Carnage Vision" (Obscure Spectre, 1997) on which the mad prophet John Trent from John Carpenter's In the Mouth of Madness commentates: "Every species can smell its own extinction. The last ones left won't have a pretty time of it".

In the long prelude to "darkpsy" - which emerged in the post-Iraq invasion period as a distinctly faster and darker style of psychedelic trance-Gil selected the sounds of the coming "night music", curating soundscapes echoing sine waves of struggle and sounding out notes of despair sampled from horror cinema. With the advent of "darkpsy", producers sought to convey states of inner chaos, fear and hopelessness, most often associated with those terrifying moments when tormented and distraught screen actors are confronted with their own demise or when serial killers and other domestic monsters kettle the vulnerable inside grindhouse storylines. Much of this material is produced by Goa artists experimenting with moods of the kind that Gil exploits to his own designs: demolishing the self in a ritual of transformation. In the strategic manipulation of the sounds of despair by Gil and other DJs, these productions sonify the impending annihilation of ego. Thus the fate of cinematic victims allegorizes the fate of the ego in sympathy with the metaphysical pretense of Gil and his ilk. Among the earlier, pre-darkpsy tracks to connote this mood, and included in the first "Divine Dozen" listed online, was the mind-bending "Plutonica" by the Ray Castle and Nick Taylor outfit Rhythmystec (E.P. Cathexis, 1996), ${ }^{33}$ which launched an arsenal of vocal samples from Joseph Campbell ready-made for Gil's divine mission: "the god of death is the lord of the dance", "it's a good day to die" and "from death comes life". Here, Gil is apparently fulfilling his duty as "God's instrument", a spiritual warrior who implements a sonic dramatization of the Dark Age, the degenerative age of the Kali Yuga. Take a selection from Gil's jarringly mixed album Kali Yuga (2009), "Crucial Night" by Fatal Discord, where death-rattle bass-lines smother hopeless cries ripped from Saw $I V$, with a shrieking that might be the siren of your own demise. Russian artist Enichkin's furious "Visit to Eternity" summons Hell's own legions. And by the time we arrive at "Kali Does The Dance" by The Nommos, descent into chaos is near complete. 
In a curious break in the fury, and signaling Gil's "worldbridging" efforts, the track samples lines from The Anjuna Jam Band (in which Gil played guitar, circa 1975-76):

\author{
C6 Kali does the Dance, \\ the Dance of Destruction. \\ Shiva lays down, \\ to watch the action.
}

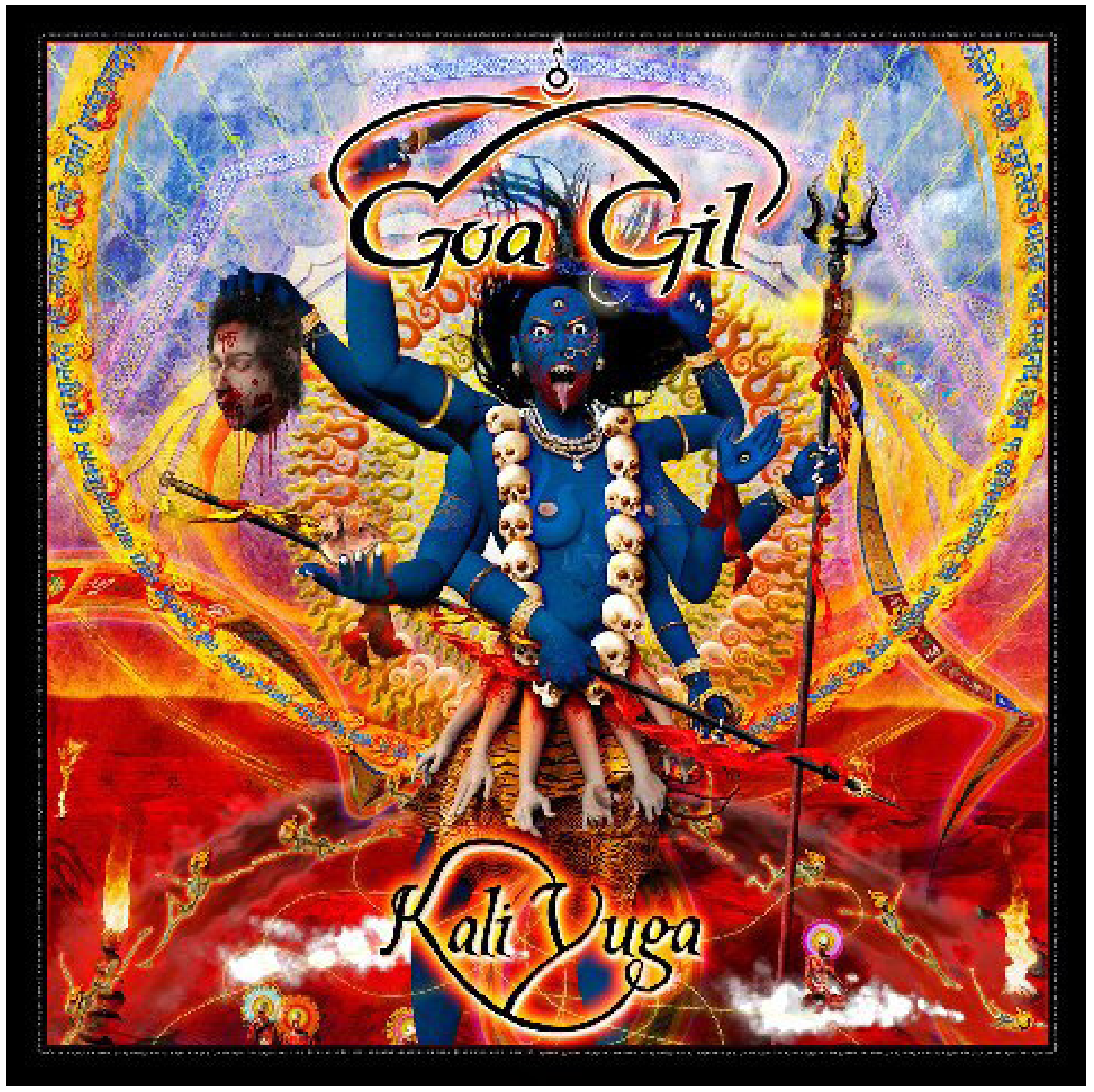

Figure 11. Cover artwork on Goa Gil's compilation Kali Yuga (2009). 
KALI IS SAID TO BE "the destroyer of false consciousness" and the "goddess of protection". On the album cover (see fig. 11), blue skinned, hair disheveled, tongue lolling, in a necklace of human skulls, Kali grasps a decapitated demon's head in one of her eight hands and wields a bloodied sword in another. While for Gil, Kali's mythic fury is a means to a revitalizing possibility, for many dark trance producers, madness, schizoid tendencies and mind-altering excesses fuel the disturbing possibilities of the liminal mind, the darker recesses of which were early explored by, for instance, Neuromotor (Neuro Damage, 2001), Psychotic Micro and Azax Syndrome collaborating on Voices of Madness (2003), and Scatterbrain (notably Infernal Angel, 2003), all pre-rabid BPM excursions into the shadowlands without obvious ritual objective. In his study of darkpsy, a "characteristically demented atmosphere" which he states is preoccupied with the "continuous transgression of its own perverted boundaries", Botond Vitos (2009: 137) contends that, fuelled by psychedelics, the darkpsy dance floor embraces "the immensity of Otherness out 'there', without transferring it 'here' (without integrating it into the Self, thus dissolving or understanding it)". Though darkpsy producers and other inhabitants of the night may become bent on an "inverted sublime", dwell in the discord of the gothic liminal, squat the post-apocalypse, or even embrace death as a lifestyle thematic, this is not the stated goal and persistently staged performance of Gil, for whom death is a threshold of transition for rebirthing neophytes. Far from reveling in the terror residing in a secularised universe in which the divine order has lost its significance-the source of discomfort of the greatest magnitude according to Douglas E. Cowan (2008) in his study of religiously-oriented horror films-Gil ultimately pursues an order which he is instructed (by the "Cosmic Spirit") to implement. And so, in recent years, Gil's own productivity appears to have escalated mirroring the inclement times. Amid the unforgiving pace of The Nommos' "Hate Killer" (Ten Reasons to Eat Dust, 2010), cinematic samples from horror cinema - "nightmares, heart palpitations, terrors"-prefigure the response as party-goers are subject to an apocalyptic sound-bath. Is it coincidental that the name for Gil and Ariane's outfit ${ }^{34}$ bears striking resemblance to the Greek word for law, rules, codes and forms - nomos - which, incidentally, in the sociology of Peter Berger, means the social order that is projected and internalised (taken for granted) within a socially constructed universe? Indeed, the Bergerian understanding of the socially established nomos "as a shield against terror" (1967: 22) appears to reveal the purpose of Gil's own religious mission: the provision of stability and connectedness in a world of chaos, separation and anomy. It might be postulated that Gil's highly regulated rituals actually hypostasize the anomalous with the objective of producing its opposite: nomisation. Under this logic, divinity and morality follow heavy doses of apocalyptic liminality.

But the net-effect of Gil's will on new generations of psychedelic trance enthusiasts who've never set foot in Goa (at least, in its heyday) remains uncertain. Detailed ethnographic attention to the motivations and outcomes of participants - their nomisation, or otherwisewould be required. Yet, it might be suggested that urban trancers living in depressing social and political conditions and intimate with a state of emergency (e.g. Israelis), who achieve the "exile vibe" with the aid of a maddening catalogue of psychochemical substances, and 


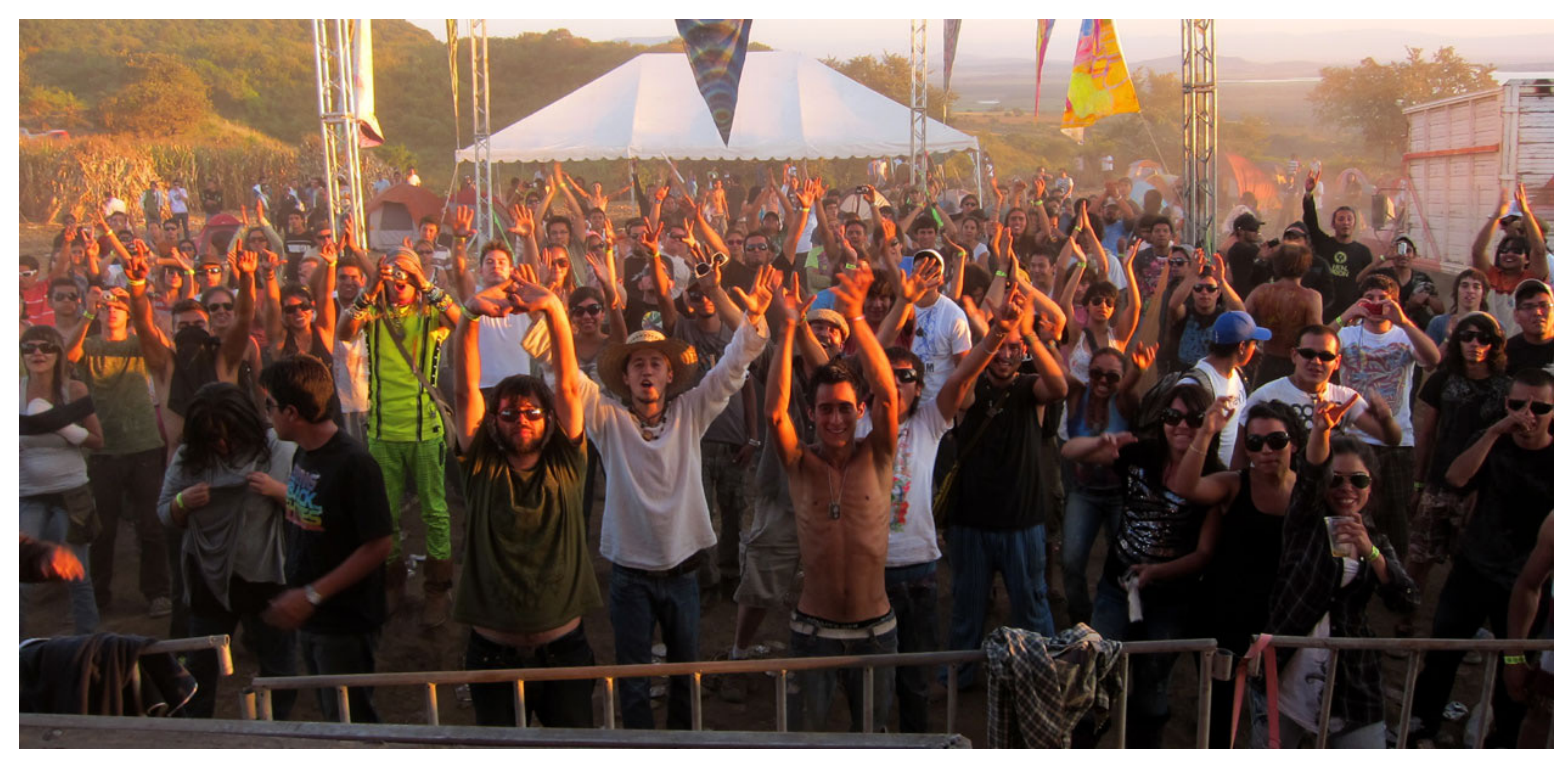

Figure 12. Recent party photo. Mexico, 2010. Photo: Goa Gil.

who syncopate increased doses with accelerated beats, may simply be carving wild shapes to aggressive soundtracks which, according to Steve Goodman (2004), "sonically enact the demise of Babylon". Nevertheless, Gil's popularity among those he once referred to as "the Children of Babylon" continues. According to historian of ecstatic dance Chiara Baldini, for these neo-trancers he is a "grandfather figure". In Italy, she says, "they call him Il Nonno. ... He is one of the original Goa freaks, so these kids who are too poor to travel and whose life is too 'normal' to be freaks they love him!... For these kids he is really a redeemer and his sets are really a powerful experience". ${ }^{35}$

At Angel's Camp in October 2006, Gil served up a ruinous, unrelenting barrage of white label dark matter, amplified well past dawn. Soaring melodies typical to the Goa tradition were absent, as were the uplifting "progressive psychedelic" motifs consistent with outdoor psytrance events where the Sun's emergence signals a shift from frenetic to softer, slower burning arrangements, ostensibly marking a corresponding elevation in consciousness. There was little variation in style at Angel's Camp, nor apparently anywhere Gil plays his DAT, including venues in fresh regions holding the possibility of visiting Armageddon (or perhaps Karmageddon, the title of his 2005 compilation) upon the psyches of dilettantes. But while I personally felt no redemption, a persistent legacy is performed: the apocalyptic remit to re/animate young neophytes, and to push them under the wheels of a rolling furor. The sonic sadbu is himself like a psy'ed-piper of the zombie whose shambling ekstasis is not far removed from the goal of meditative traditions: the dissolution of subjectivity and the potentiation of mystical states of consciousness. As I explain elsewhere (St John 2011), embodying the hyper-anomalous condition of living-death, the zombie is a cardinal trope within psytrance and is something of a parodic mascot for the dark carnival. There, it holds court as a powerfully ambiguous device, loaded with potential. Passing into (ego) death and 
yet (charged) alive, the zombie is a liminal figure emblematic of the altered conditions of mind and flesh experienced as "trance". Anaesthetized yet mobilized all the same, the zombie embodies the unpredictable yet potentially transcendent and revitalizing conditions of the dance floor.

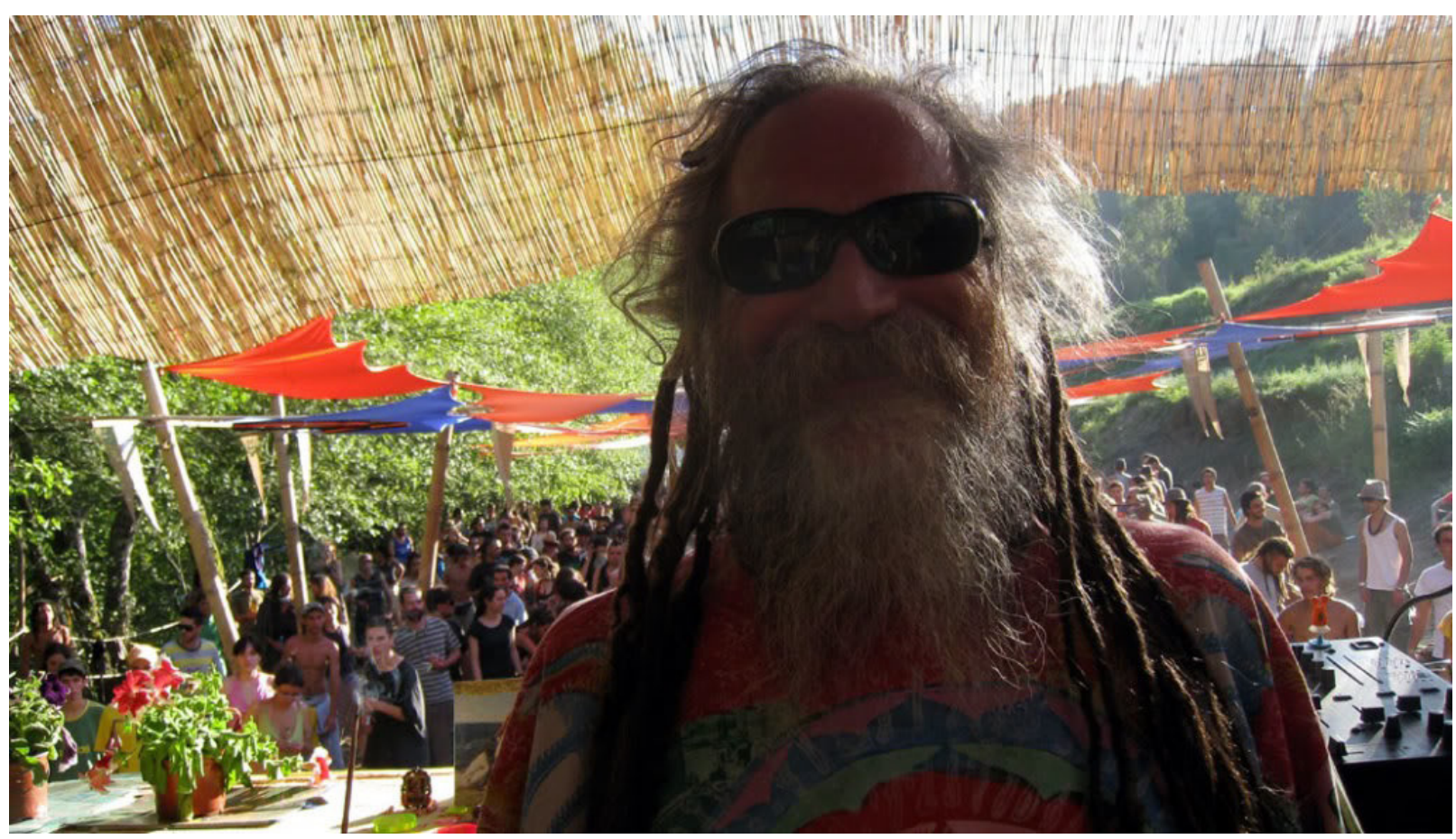

Figure 13. Goa Gil party. Portugal, 2008. Photo: Ketamina Mestre.

WITH BEARD BLAZING GREY, rocking from side to side, bearing a wide grin, Gil makes himself heard under this aberrant aesthetic. Sadhu punk and servile master of a brutal exercise in zombification, he assumes his staged position as head mutant in this "apocalypse culture", his interventions straddling inchoate purposes: the annihilation of subjectivity and social re-animation. Like a faithful servant of the apocalypse, Gil casts his shadow over the dance floor. And exercising a kind of sonic homeopathic logic, he submits all to his abominable symphony. As the snap shots and videos he routinely captures of the "Children of Babylon" from his DJ position illustrate, massives willingly surrender to Gil's will. ${ }^{36}$ But the ritual has given cause to considerable unease, upsetting especially to those for whom the Sun's rising is the singular transition towards consciousness expansion, "dawning" or "awakening"-a transition that is apparently abused by Gil, whose "apocalypse now" appears to know no bounds. At least this is the view of Castle, who last heard Gil play in 2005 at the foot of Mt Fuji, Japan. "This dark monotonous moronic dirge bleak psychotic sound continued into the sun rise", he lamented. ${ }^{37}$ "It was dreadful, just like this dark tunnel all night and into the morning, and it was just nothing like I remember from when I used to DJ with 
him together in 1991 in Goa. He'd completely lost the plot.... I think he undermines any vestige of idealised spirituality or healer facilitator that he may have tried to project". ${ }^{8}$ In a final rebuke, his "diabolical dark trance" has "self-defeated his philosophy of making the journey from dark into light". Castle is not alone in his criticism. While Pavel (2010), for instance, argues that "the music that he plays today is depressing, violent and completely random", others crave for the good old days: "Bring back the music that made us love Goa Gil. Today's Goa Gil sets drive us away, and splinter the already fragmented scene. Let us all gather together again as one goa trance family and dance like we did in the good old days. We'll trade his newer, smooth mixing style and nails-on-chalkboard music for the preferred GOA music and DAT mixing" (Phil G 2008).

\section{THE "SUX / ROX POLARITY"}

From THE SELF-EXILES who inhabited the freak vibe on Goa beaches in the 1970s/1980s, to today's domestic enthusiasts immersed in the dark psychedelic trance that he has adopted as his sonic signature, Gil has traversed diverse scenes. As Gil reflects on Goa, "we came here so long ago, to the end of a dirt road and a deserted beach. It was like the end of the world. And now the whole world is at our doorstep" (Davis 1995). As the transposable assemblage was transported to audiences world-wide after parties grew increasingly untenable at their place of genesis, and as "Goa trance" emerged as an international returned-traveller phenomenon and marketable genre, Gil became a global smuggler of "the end of the world", commanding a sustained sonic broadside into the solar plexus of the devoted and bemused alike. But Gil's is far from being the undisputed aesthetic uniting the psytrance massive. Victoria Bizzell holds that Gil is as "extremely palatable, and transportable ... charismatic representative of rave culture's transnational neo-tribal ideology". But while she finds it noteworthy that "Gil's party concept and the Goa trance party in general have struck such an emphatic chord in a globally dispersed audience" (2008: 289), as I've attempted to illustrate, while continuing to attract devotees, Gil strikes considerable discord among descendants of psychedelic trance, which I would argue echoes the fact that "neo-tribalism" is not uniform, that it accommodates disparate positions and conflicting publics including those who will embrace and reject Gil, along with those who are indifferent to his agendas. Elsewhere I have argued that "tribalism" resonates with EDM communities precisely because it signifies "one" and "many", the dissolution and performance of difference (see St John 2009a: 93-164).

While his current impact may be overstated, there is no denying that when the subject of Goa Gil is raised within Goa/psytrance circles, opinions aren't hard to come by, and they quickly fall into polarized camps. The isratrance.com web-portal offers evidence of the controversy. The posting of a link to a video of Goa Gil interviewed in Berlin in 2007 where he answers inquiries about his religious background, his initiation and spiritual practice, triggered a 22-page thread (at the time of writing) in which one can find torrents of veneration and vitriol. While there are respectful endorsements of the "godfather" of the scene with "superhuman" capabilities, and enthusiastic young trancers are enamored with 
Gil whether they "get" his missionary intent or not, others take exception to any hagiolatry; the practice of "worshipping" and idolizing performed by supporters. ${ }^{39}$ On 17 May 2007, the discussion compelled one poster, "v.v2", to inquire: "why does everyone get so riled up at the mention of Gil? why is the house always divided, and vehemently so?". Reasonable questions, and although "Maine Coon", contributing to the thread more than three years later, called attention to the "sux / rox polarity", the explanation for such disparity had hardly been addressed.

This article has shown that Goa Gil manifests as a polyvalent symbol for participants in the psychedelic diaspora and is iconic among proponents and detractors of "psytrance" and "darkpsy" alike. For those initiates who have regarded psychedelic trance as a vehicle of hope and peace, Gil-who is heir not only to the Haight-Ashbury psychedelic scene of the 1960s, but to ancient mystical and ecstatic cults, the connections with which are both sanctioned and nebulous-possesses the right stuff. For others, the failure of Goa trance to meet its millenarian promise has generated heated reactions, both from within and outside of the scene, with detractors charging psytrance as a hubristic behemoth that has collapsed under the weight of its own contradictions. Gil is ultimately iconic of tensions within a diverse movement, tensions which I expand upon elsewhere (see St John, Forthcoming). Loved as a champion of the Goa vibe, and loathed as symbol of the contradictions that have befallen it, Gil pitches like a weather balloon in a storm. But Gil, who will turn 60 in 2011, stands fast over 40 years since he first set foot on Anjuna beach. And the question of whether he is venerable or reproachable may never be finally settled — for that is the fate of anomalies.

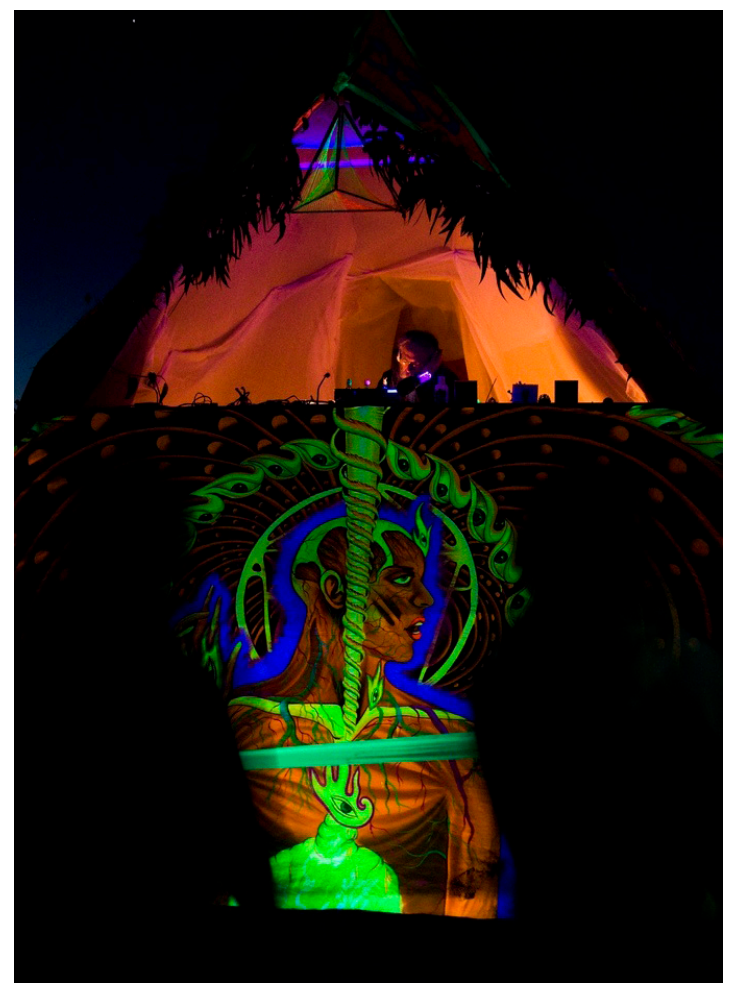

Figure 14. Goa Gil party, Chile, 13 November 2010. Photo: Lautaro Salinas. ${ }^{40}$ 


\section{ACKNOWLEDGMENTS}

Many thanks especially to Goa Gil, Ray Castle, Swami Chaitanya, Peter Ziegelmeier and Steve "Madras" Devas, with whom I conducted interviews, had email communications and otherwise berated with questions for this article, and who commented on section drafts. Thanks also to Chiara Baldini and Joshua Schmidt who read and offered insights on previous drafts, to one of the reviewers for useful suggestions and insights, and to Jérôme Hansen for his expert copyediting. Appreciations to Goa Gil, Gilbert Garcia, Ketamina Mestre and Lautaro Salinas for permitting my reproduction of their photographs. And thank you too to Jay, Michael and Jen with whom I travelled to Angel's Camp back in October 2006.

\section{ENDNOTES}

1 The DAT (digital audio tape) recorder/player has been Gil's instrument of choice since he used the Sony D3 model (produced in 1991).

2 While Gil informed me by email on 24 November 2010 that he had "no idea" how many 24hour events he has played (or rituals he has performed), my guestimate is about 500 (though the number of events at which he has DJed will be considerably more).

3 <http://www.goagil.com/> (accessed 10 March 2011).

4 As documented in his unpublished autobiography (Eight Finger Eddie, n.d.). Eddie died in Goa on 18 October 2010.

5 Swami Chaitanya, interview with the author, San Francisco, 19 November 2006.

6 As Steve "Madras" Devas recounted: "as is well known, The Who used Marshall amps and had begun to smash them at the end of gigs. Marshall Co. saw this as promotional, an advertising stunt, and promised them free gear if they continued the practice. Consequently, The Who had lots of spare gear on their hands (It's hard work destroying a Marshall amp, the novelty wears off, 'hey, let's keep some of it. .')" (email to the author, 11 March 2011).

7 Steve "Madras" Devas, email to the author, 11 March 2011.

8 Goa Gil, email to the author, 9 March 2011.

9 Goa Gil, email to the author, 9 March 2011.

10 But Gil was not the only DJ pioneer. Crucial were those like Anders, a Swedish film-maker and DJ whose early footage of Anjuna parties offers one of the only extant collections of early 1970s lifestyle. According to Devas (email to the author, 27 March 2011), "Anders brought a jazz funk flavour to the parties playing Herbie Hancock, Brazilian soul funk and the like". Space does not permit mention of several other early DJ pioneers who were also prominent in developing what Devas calls the early Anjuna "cosmo rock" sound.

11 Steve "Madras" Devas, email to the author, 10 March 2011.

12 Steve "Madras" Devas, email to the author, 13 March 2011.

13 Steve "Madras" Devas, email to the author, 10 March 2011.

14 Goa Gil, email to the author, 9 March 2011.

15 Goa Gil, email to the author, 14 January 2011. 
16 Peter Ziegelmeier, interviewed at Ceiba Records, Haight St, San Francisco, 27 November 2006.

17 Steve "Madras" Devas, email to the author, 10 March 2011.

18 Ray Castle, interview with the author (online via Skype), 7 February 2011.

19 Steve "Madras" Devas, email to the author, 27 March 2011.

20 Ray Castle, interview with the author (online via Skype), 7 February 2011.

21 Steve "Madras" Devas, email to the author, 10 March 2011.

22 Ray Castle, email to the author, 7 March 2011.

23 Shaktipat is a Sanskrit term referring to the conferring of spiritual "energy" upon one person by another.

24 Referring to a higher level of concentrated meditation.

25 Ray Castle, interview with the author (online via Skype), 7 February 2011.

26 Not exclusively, since Ariane also performs.

27 Michael McAteer (2002: 25) adds some insight here, stating that Goa Gil "held the seat of his deceased guru within the compound of the Juna Akara in the 2001 Maha Kumbha Mela. The Juna Akara is the largest brotherhood of sadhus in India, particularly known for their fearsome roughness. The fact of Gil's holding the seat of his guru at the Maha Kumbha Mela, is testament to his sanctioned status within the traditional Hindu world".

28 Along with Vasudev Puri and Baba Rampuri, the author of Baba: Autobiography of a BlueEyed Yogi (2005).

29 Goa Gil, email to the author, 6 January 2011.

30 Goa Gil, email to the author, 6 January 2011.

31 Divine Dozen: <http://www.goagil.com/chart.html> (accessed 10 March 2011).

32 Mark Petrick (aka Xenomorph), email to the author, 15 November 2010.

33 The EP is included on Gil's first Divine Dozen he listed online.

34 The Nommos is the name and a Dogon word referring to amphibious beings and guardians "from somewhere in the vicinity of the star we call Sirius B" (as described on the inlay of debut album Digitaria, 2004). Their first track release (on Spiritual Trance Vol. 2, 1995), "Po Tolo" (the Dogon name for the star Sirius B), features the sample "we have watched the skies and waited”, along with what Gil informed me are samples from a Dogon death ceremony. Goa Gil, email to the author, 10 May 2009.

35 Chiara Baldini, email to the author, 10 March 2011.

36 Since October 2004, Gil and Ariane have kept a vast archive of photographs and videos mostly shot from Gils' DJ-position. At: < http://www.goagil.com/photogallery >. For examples of Gil and Ariane's videos, see Gil-vision (2005, 2007).

37 Ray Castle, email to the author, 12 November 2010.

38 Ray Castle, interview with the author (online via Skype), 7 February 2011.

39 See thread, "Video Interview with GOA GIL", at < http://forum.isratrance.com/videointerview-with-goa-gil/> (accessed 10 March 2011). For the video interview conducted in Berlin in 2006, see Time Wave Zero (2006).

40 <www.flickr.com/photos/unaqueotraalucinacion>. 


\section{REFERENCES}

Agamben, Giorgio. 1998. Homo Sacer: Sovereign Power and Bare Life. Stanford: Stanford University Press.

Baldini, Chiara. 2010. “Dionysus Returns: Tuscan Trancers and Euripides' The Bacchae”. In The Local Scenes and Global Culture of Psytrance, ed. Graham St John, 170-85. New York: Routledge.

Beck, Giles and Gordon Lynch. 2009. “'We Are All One, We Are All Gods': Negotiating Spirituality in the Conscious Partying Movement". Journal of Contemporary Religion 24(3): 339-55.

Berger, Peter L. 1967. The Sacred Canopy: Elements of a Sociology of Religion. New York: Anchor Books.

Bizzell, Victoria. 2008. “'Ancient + Future = Now': Goa Gil and Transnational Neo-Tribalism in Global Rave Culture”. Comparative American Studies 6(3): 281-94.

Cole, Fred, and Michael Hannan. 1997. "Goa Trance”. Perfect Beat 3(3): 1-14.

Cowan, Douglas E. 2008. Sacred Terror: Religion and Horror on the Silver Screen. Waco, TX: Baylor University Press.

D’Andrea, Anthony. 2007. Global Nomads: Techno and New Age as Transnational Countercultures in Ibiza and Goa. New York: Routledge.

Davis, Erik. 1995. "Sampling Paradise: The Technofreak Legacy of Golden Goa”.. Option 61. Available at: <http://www.techgnosis.com/index_paradise.html> (accessed 10 March 2011).

Diken, Bülent and Carsten Bagge Laustsen. 2004. "Sea, Sun, Sex ... and Biopolitics”. Lancaster University, Dept Sociology, Online Papers: <http://www.lancs.ac.uk/fass/sociology/papers/ diken-laustsen-sea-sun-sex-biopolitics.pdf $>$ (accessed 10 March 2011).

Eight Finger Eddie. n.d. My Rise to Relative Obscurity: 1924-1972. Available at: <http:// www.8fingereddie.com/downloads.html> (accessed 10 March 2011).

Elliott, Luther. 2010. "Goa is a State of Mind: On the Ephemerality of Psychedelic Social Emplacements". In The Local Scenes and Global Culture of Psytrance, ed. Graham St John, 21-39. New York: Routledge.

ENRG, Eugene (DJ Krusty) interviews Ray Castle. 2001. "Psychic Sonics: Tribadelic Dance Trance-formation". In FreeNRG: Notes From the Edge of the Dance Floor, ed. Graham St John, 157-69. Melbourne: Common Ground. Available at: < http://undergrowth.org/ freenrg notes from the edge of the dancefloor $>$ (accessed 10 March 2011).

Freeze Magazine. 2001 (Aug). Interview with Goa Gil. Issue \# 14: < http://www.goagil.com/ FreezeInterview1.html > (accessed 10 March 2011).

Goodman, Steve. 2004. “Speed Tribes: Netwar, Affective Hacking and the Audio-social”. In Cultural Hacking, ed. Franz Liebl, 139-56. Vienna: Springer.

Gosney, Michael. 1997 (Oct). Interview with Goa Gil. Radio V: < http://radiov.com/main/ beam/innerviews/goagil > (accessed 10 March 2011).

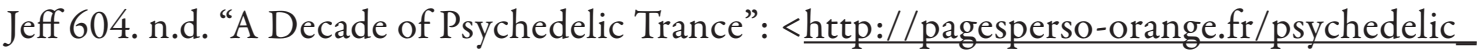
trance/> (accessed 10 March 2011).

McAteer, Michael. 2002. “Redefining the Ancient Tribal Ritual for the 21st Century': Goa Gil and the Trance Dance Experience”. BA Thesis (Philosophy, Religion, and Psychology), Reed College. Available at: <http://www.goagil.com/thesis.html > (accessed 10 March 2011).

Pavel. 2010. Posting to thread "Video Interview with GOA GIL". Isratrance. 3 September $<$ http://forum.isratrance.com/video-interview-with-goa-gil//> (accessed 10 March 2011). 
Phil G. 2008. “The Goa Gil Petition: Play Those DATS!” Beatportal. 24 January: < http://www. beatportal.com/feed/item/the-goa-gil-petition-play-those-dats/> (accessed 10 March 2011).

Rampuri, Baba. 2005. Baba: Autobiography of a Blue-Eyed Yogi. New York: Bell Tower.

Rietveld, Hillegonda. 2010. "Infinite Noise Spirals: Psytrance as Cosmopolitan Emotion". In The Local Scenes and Global Culture of Psytrance, ed. Graham St John, 69-88. New York: Routledge.

Rom, Tom and Pascal Querner. 2010. Goa: 20 Years of Psychedelic Trance. Solothurn, Switzerland: Nachtschatten Verlag.

Schmidt, Joshua I. 2010. “(En)Countering the Beat: Paradox in Israeli Psytrance”. In The Local Scenes and Global Culture of Psytrance, ed. Graham St John, 131-48. New York: Routledge.

St John, Graham. 2009a. Technomad: Global Raving Countercultures. London: Equinox.

- - . 2009b. "Neotrance and the Psychedelic Festival". Dancecult: Journal of Electronic Dance Music Culture 1(1): 35-64. <http://dx.doi.org/10.12801/1947-5403.2009.01.01.03>.

_- _. 2011, forthcoming. "Rave from the Grave: Dark Trance and the Return of the Dead". In Zombies Are Us: Essays on the Humanity of the Walking Dead, ed. Cory James Rushton and Christopher M. Moreman. McFarland.

_-_. 2012, forthcoming. "Freak Media: Vibe Tribes, Sampledelic Outlaws and Israeli Psytrance". Continuum: Journal of Media and Cultural Studies.

- - Forthcoming. Global Tribe: Technology, Spirituality and Psytrance. London: Equinox.

St John, Graham and Chiara Baldini. 2011, forthcoming. "Dancing at the Crossroads of Consciousness: Techno-Mysticism, Visionary Arts and Portugal's Boom Festival”. In Handbook of New Religions and Cultural Production, ed. Carole M. Cusack and Alex Norman. Leiden: Brill.

Time Wave Zero (aka Tina). 2007. Posting to thread "Video Interview with GOA GIL". Isratrance. 10 May <http://forum.isratrance.com/video-interview-with-goa-gil/> (accessed 10 March 2011).

van Veen, tobias, c. 2010. “Technics, Precarity and Exodus in Rave Culture”. Dancecult: Journal of Electronic Dance Music Culture 1(2): 29-49. <http://dx.doi.org/10.12801/ 1947-5403.2010.01.02.02>.

Vitos, Botond. 2009. "The Inverted Sublimity of the Dark Psytrance Dance Floor". Dancecult: Journal of Electronic Dance Music Culture 1(1): 137-41. < http://dx.doi.org/10.12801/ 1947-5403.2009.01.01.10>.

\section{DISCOGRAPHY}

Alien Mental. 2007. Mind Hack. Insomnia Records (CD): INSOCD10. <www.discogs.com/Alien-Mental-Mind-Hack/release/1153306>.

Goa Gil. 1995. Spiritual Trance Vol. 2. Javelin (CD, Comp, Mixed): 3014572. <www.discogs.com/Goa-Gil-Spiritual-Trance-Vol-2/release/127984>.

- - 2005. Karmageddon. Avatar (CD, Comp, Mixed): AVA029. < http://www.discogs.com/Goa-Gil-Karmageddon/release/448510>.

- - 2007. Worldbridger. Avatar (CD, Comp, Mixed): AVA042 <http://www.discogs.com/Goa-Gil-Worldbridger/release/1013929>. 
- - 2009. Kali Yuga. Avatar (CD, Comp, Mixed): AVA057.

$<$ www.discogs.com/Goa-Gil-Kali-Yuga/release/1846310 >.

Jungle High. 1992. Jungle High. Logic Records (12-inch): LUK011.

<www.discogs.com/Jungle-High-Jungle-High/release/177016>.

KLF, The. 1988. What Time is Love? (Pure Trance 1). KLF Communications (Vinyl, 12inch): KLF 004T. < http://www.discogs.com/KLF-What-Time-Is-Love-Pure-Trance-1/ release $/ 92768>$.

Neuromotor. 2001. Neuro Damage. Acid Dance Records (CD): ACIDCD003. <www.discogs.com/Neuromotor-Neuro-Damage/release/94891>.

Nommos, The. 2004. Digitaria. Avatar (CD): AVA0203302282. <www.discogs.com/Nommos-Digitaria/release/223921>.

Overlords, The. 1991. Sundown. Antler-Subway (CD, Maxi-Single): AS 5051CD. <http://www.discogs.com/Overlords-Sundown/release/176853 $>$.

Psychotic Micro and Azax Syndrom. 2003. Voices of Madness. Parvati (CD, Comp): PRVCD04. <http://www.discogs.com/Psychotic-Micro-Azax-Syndrom-Voices-Of-Madness/ release $/ 240188>$.

Rhythmystec. 1996. Cathexis. Matsuri (12-inch): MP18. <www.discogs.com/Rhythmystec-Cathexis-EP/release/141215>.

Scatterbrain. 2003. Infernal Angel. Digital Psionics (CD): DPSICD07. $<$ www.discogs.com/Scatterbrain-Infernal-Angel/release/215319>.

Ten Reasons to Eat Dust (compiled by Umbra). 2010. $5^{\text {th }}$ Element Records (CD, Various Artists): 5thcd005. <http://www.discogs.com/Umbra-Ten-Reasons-To-Eat-Dust/release/2318995 >.

Xenomorph. 1997. Obscure Spectre. Koyote (CD, Single): kr013scd. <www.discogs.com/Xenomorph-Obscure-Spectre/release/183952>.

\section{FILMOGRAPHY}

Cohn, Fred. 1973. Sunseed. USA: New Age Productions and Ram Films Inc. <http://www.imdb.com/title/tt0948127>.

Devas, Darius. 2010a. "Eight Finger Eddie". A segment of the SBS multimedia documentary Goa Hippy Tribe filmed and directed by Darius Devas on Anjuna Beach, Goa, January 2010. <http://www.facebook.com/home.php\#!/video/video.php?v=10150167845795322> (accessed 10 March 2011).

_- - 2010b. Steve "Madras" Devas. A segment of the SBS multimedia documentary Goa Hippy Tribe filmed and directed by Darius Devas on Anjuna Beach, Goa, January 2010. $<$ http://www.facebook.com/video/video.php?v=10150163765975322> (accessed $10 \mathrm{March}$ 2011).

Gil-vision. 2005. Video shot by Gil at a party in Chile in 2005.

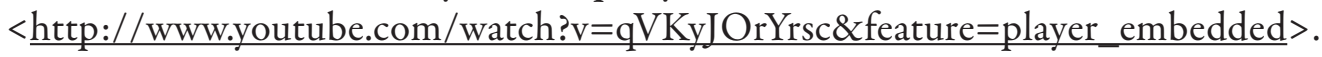

——_. 2007. Video shot by Gil at a party in Mexico in 2007. $<$ http://www.youtube.com/watch?v=Up7zNiERZR8\&feature=player_embedded $>$.

Time Wave Zero. 2006. Goa Gil: The Godfather of Goa Trance. <http://video.google.com/videoplay?docid=-1339500396225064783\&\#035>. 